\title{
The Employment Impact of Poland's Special Economic Zones Policy
}

\author{
Jensen, Camilla
}

Document Version

Accepted author manuscript

Published in:

Regional Studies

DOI:

$10.1080 / 00343404.2017 .1360477$

Publication date:

2018

License

Unspecified

Citation for published version (APA):

Jensen, C. (2018). The Employment Impact of Poland's Special Economic Zones Policy. Regional Studies, 52(7), 877-889. https://doi.org/10.1080/00343404.2017.1360477

Link to publication in CBS Research Portal

\section{General rights}

Copyright and moral rights for the publications made accessible in the public portal are retained by the authors and/or other copyright owners and it is a condition of accessing publications that users recognise and abide by the legal requirements associated with these rights.

Take down policy

If you believe that this document breaches copyright please contact us (research.lib@cbs.dk) providing details, and we will remove access to the work immediately and investigate your claim. 


\section{The Employment Impact of Poland's Special Economic Zones Policy}

\section{Camilla Jensen}

Journal article (Accepted manuscript*)

\section{Please cite this article as:}

Jensen, C. (2018). The Employment Impact of Poland's Special Economic Zones Policy. Regional Studies, 52(7), 877-889. 001: 10.1080/00343404.2017.1360477

This is an Accepted Manuscript of an article published by Taylor \& Francis in Regional Studies on 01 Sep २०17, available online:

DOl: http://www.tandfonline.com/10.1080/00343404.2017.1360477

* This version of the article has been accepted for publication and undergone full peer review but has not been through the copyediting, typesetting, pagination and proofreading process, which may lead to differences between this version and the publisher's final version AKA Version of Record. 


\title{
Employment in Transition - The Case of Poland's Special Economic Zones
}

\author{
Dr. Camilla Jensen \\ Copenhagen Business School
}

May 25, 2017

\begin{abstract}
Poland launched in 1994 a special economic zones experiment to maintain employment structures outside the major cities. Using difference-indifference estimations it is evaluated whether the policy has been successful in its primary objective which is to sustain employment in gminas (municipalities) more likely to be negatively affected by the economic transition. A significant and positive effect of the policy on employment is documented. But with some negative spillovers at the policy level as zones start to spread rapidly. Accounting for covariates, timing, policy spillovers and reducing imbalance through matching the average treatment effect for employment is estimated to be $60 \%$.

Keywords: Policy impact evaluation, regional economic development, special economic zones, economic transition

JEL Codes: C33, L53, P25, R58
\end{abstract}




\section{Introduction}

Poland introduced early on in its transition process a policy experiment aiming to give incentive to regional employment. Following the act (of October 20th, 1994) that introduces the zones, this experiment is entitled the Special Economic Zones policy or referred to also in brief as the 'zones policy' in this paper. In hindsight the Polish zones policy proves to be one of the largest social experiments in the cross between economic geography and economic transition in recent time. The only other parallel experiment to this is the Chinese. However, that experiment lends very little resemblance with the Polish because its focus has been the opposite. While China's economic zones have reinforced the process of economic agglomeration (as the zones are located in or adjacent to some of China's major cities and from the beginning only targeting the most developed and coastal regions), Poland's aim to do the opposite by keeping employment with a less urban, partly rural or semi-urban population thereby giving incentive to a pattern of employment outside the traditional and major urban centers on the L running from Gdansk to Poznan to Warsaw.

\subsection{Towards a theory of economic zones}

The theory of economic zones has since Grubel's seminal contribution (Grubel, 1982) on the political-economy of free trade zones remained relatively undeveloped. This owes in large part to the great heterogeneity in the phenomenon of economic zones, whether designed for suiting purposes of balanced or unbalanced growth (Litwack and Qian, 1998) or to facilitate international trade as part of their mandate. Economic zones theory belongs to the area of international economics called 'selective interventionism' (Westphal, 1990, Rodrik, 2008). Over time and as these type of policies have developed, they have started to take more importance to regional economics as often they involve a spatial dimension or place-based orientation (Barca et al, 2012). For example, Levien (2012) suggests that zones serve a purpose of cementing institutional claims in feuds over land between farmers and manufacturers. Since Grubel's paper hence selective intervention has been increasingly steered towards that of the regional political-economy and away from the international political-economy, even though arguably the policy could still be tailored to incorporate aspects of discrimination. Part of the challenge of economic transition also concerns the political-economy of building free market economic institutions towards regulating land usage and establishing a new balance between major cities, other urban and rural areas. It is also here that the theorizing of economic zones has found its renaissance in the context of transition economies. Litwack and Qian (1998) in the context of China and Russia suggest that zones serve the dual purpose of social control and institution building. Park (2005) argues that traditional uses of space and the purpose of new institutions are thought together using zones as combined tools of reconstructivism. 


\subsection{Previous findings on employment effects of zones type policies}

In a study of the Polish zones policy by Cizkowicz et al (2016); where the authors use aggregate firm-level data at the combined zones and poviat level (based on a dataset collated by the Ministry of Economy in Poland); it is possible to estimate quite accurately the spillover effects (in those areas where the policy has been successful in creating in-zone development) due to the availability of data on the direct employment effect of the zones policy. The authors find a positive spillover effect of the policy on employment and a neutral spillover effect on investment in Poland. Another study by Ambroziak (2015) suggests that there was no impact of the zones policy on the unemployment rate at the level of poviats. A study by Jensen and Winiarczyk (2014) using a simple difference-in-difference estimator showed that there was a small but positive effect of the zones policy on employment at the gmina (LAU2 - see footnote 1 further below) level. While the study by Cizkowicz et al is biased as a de facto policy evaluation in view to its emphasis on spillovers from only those zones that exhibit a positive development in terms of direct employment effects, the other available more traditional policy evaluation studies have in common that the policy variable lacks variability in the time dimension of its application. Furthermore, none of the available studies controlled for a potential selection bias, nor were robust methods deployed towards combating imbalances in the dataset due to area heterogeneity when comparing the treated and non-treated areas.

Outside the Polish context there is a number of papers evaluating policies of a similar content to the Polish zones policy aiming to give incentive to employment in lesser developed regions. The longitudinal and historical study of the Tennessee Valley Authority (TVA) by Kline and Moretti (2014) reports a high and sustained impact of the place-based policy on manufacturing employment. The same authors also documented a positive net present value of the TVA (which is considered the largest place-based policy experiment in US history). For another similar US program Busso et al (2010) reported a positive employment effect without any significant social loss such as increases in rents and prices. A somewhat earlier study of the Indiana Enterprise Zone by Papke (1994) reported a reduction in unemployment claims. Biagi et al (2015) in a study of structural funds paid out as investment subsidies to firms in Italy found that there was an average effect of 2 jobs created per firm subsidized. Fertig et al (2006) review the literature and evaluate some aspects of the Active Labour Market Policy (ALMP) in Germany which also aims at boosting regional employment. The regional or macro-oriented literature suggests that the ALMP in particular when combined with monetary incentives targeted at firms had a positive impact on regional employment levels. Parallel studies of the same policy implemented in East Germany after the transition found no impact of the policy on employment (Lechner and Wunsch, 2009). Martin et al (2011) studied the impact of the French cluster policy and found no robust impact of the policy on productivity, employment and exports. A later study of the same 
or a similar policy in France (Zones Franches Urbaine) by Givord, Rathelot and Sillard (2013) documents a short-run positive employment effect but which tends to dilute over time and with strong negative spillovers on adjacent areas.

Outside the western context a number of studies into the export processing zones take a similar character. Yet the labour market context may be dissimilar and sometimes referred to as the promotion of enclave economies at the expense of long-term development goals (for a discussion see for example Rasiah and Shari (2001)). Aggarwal (2007) reports large employment gains for India but questioning the long-term value of the Indian zones policy on other human development indicators. Another study of using tax incentives for two underindustrialised provinces in India by Chaurey (2014) documents an employment effect of $37 \%$ using counter factual methods. Particular studies and review studies of the Chinese policy also document that in this aspect of policy China lends more on the experiences of developing countries using SEZs mainly as a temporary tool to join migrant labour with foreign capital (see e.g. Cheng and Kwan, 2000). As privileges of zones here diluted over time it was mainly the zones such as Shenzhen, capable of learning and adapting to the new and changing circumstances over time that benefited most from China's rather particularistic place-based policy (Yeung et al, 2009). Due to its heavy migrant labour aspect it is nearly impossible to conduct policy evaluations of the Chinese policy on longer term labour market outcomes such as employment (see e.g. Wang, 2013, Zheng et al 2015).

\subsection{Research objectives}

The main objective in this paper is to make policy evaluation using standard tools in policy analysis and economic geography of the employment aspect of the zones policy. The approach is traditional by pooling and panelling economic areas down to the most detailed level possible (LAU2 in the EU nomenclature see also Footnote 1) with and without the policy intervention. By allowing for a time varying dimension in the policy intervention itself (which is necessary as many of the areas affected are added over time as explained in Section 2) it is possible to use standard techniques such as difference-in-difference estimators to evaluate the effectiveness of the policy intervention for employment outcomes.

Many policies are evaluated as one-time events or decisions. However, the background to this policy shows that this may in practise be a mistake and that policy evaluation needs to be sensitive to timing. The extended length of the Polish policy including the fact that it contains an ex-ante and ex-post aspect in its cross with EU regional policy makes it a unique study of its kind. The political-economy surrounding this particular policy intervention or social experiment shows that it had repercussions on the policy process in other neighbouring and adjacent economic areas, even to the extent that the policy spread to occupy quite a large number of territories across Polish economic space. Initially only 14 areas (out of a total of more around 4,000 areas at the LAU2 level) were affected by the policy. However, by $201513 \%$ of gminas (municipalities) or $15 \%$ of land in Poland is under the influence of the policy according to the 
database collated (see Section 2 for a description of the database used in the study). Hence the research questions are:

- General treatment effect: Are the Special Economic Zones successful in their overall objective of sustaining regional employment during economic transition to capitalism? Is this result sensitive to counter factual checks?

- Policy and project-level level variation over time: Is the policy enduring or does the effect fade out at the policy or project level over the period of investigation?

\section{$2 \quad$ Policy background}

Following the Act of October 20th 1994 on Special Economic Zones (OJ, 2007) Poland decided relatively early into the transition period (that was initiated back in 1989) to introduce a set of special region by-laws allowing initially a few number (14) of designated areas to use tax incentives. This was seen as a special way to circumvent the employment losses anticipated to result from the restructuring and closing down of some of Poland's major state-owned enterprises (SOEs) (OJ, 2007, Article 4). Initially these designated areas were so privileged that no income tax at all was to be paid (OJ, 2007, Article 12). Also, they were to be confined in terms of the actual economic and geographical space occupied and also viewed initially as a short-termed policy easing the Polish transition up until EU accession.

But chance and political circumstance paved a quite different path for the policy. Initially the reach was confined to a maximum of only 12,000 ha of land (OJ, 2007, Article 5a) later extended e.g. to 20,000 ha in OJ (2008).

INSERT FIGURE 1 HERE

But gradually the zones have accumulated their own administrative powers and it may be this factor including the inter-zone competition surfacing among the zones administrations and what then suddenly became a demand-led development (Gwosdz et al 2008) that ignited the rapid growth in areas included under the zones policy over time (see Figure 1). New rules and regulations also developed which tended to expand the potential areas eligible to participate in the zones policy (see e.g. CoM, 2008a, 2008b). Therefore it is open to interpretation why the policy made the transition from the initial pilot phase to the roll-out phase that started in the late 1990s and early 2000s. Possibly it was related with the opportunity the policy offered in terms of combining the managerial capabilities of the zones administrations with the administrative capacity that future integration of Poland with the European Union's structural fund policy would require. Undoubtedly the initial expectations that the zones policy would be dismantled once Poland was to become a member of the European Union put an initial dampener on its reach. Hence when the main privilege of tax exemptions was renegotiated to fit with European Union law (OJ, 2003), it opened the possibility for a longer survival of the policy than perhaps initially envisioned (negotiated with the EU in 2002 and taking effect 
from 2003 onwards where the policy timeframe was extended until 2017). Then chance would that the financial crisis changed the relative negotiation power of national governments vis-a-vis the European Union. This in the case of Poland paved the way for further exemption (taking effect from 2014 onwards, where now the policy is expected to last at least until 2026, see KPMG, 2013) from a policy that is fundamentally considered to be in violation of EU Competition Law. Hence the Polish government has been able recurrently (effective in 2003 and again in 2014) to extend the phasing out of the policy, however, by also agreeing to a gradual phasing out of the tax incentives (KPMG, 2013). This will eventually ease the termination of the policy; as it is currently being phased out; but instead through a gradual erosion in tax privileges. As the reach and success of the policy has grown over time now combined with EU regional policy it may possibly have changed the long run regional development trend in Poland.

This paper attempts to evaluate such judgments on more scientific grounds, foremost by asserting whether the policy did achieve to affect the long run trend in regional employment of the areas affected by the zones policy.

\section{Data and methodology}

The data was downloaded from the Polish Local Databank over several periods. The final dataset is consolidated to cover the period 1995-2014. However, initial analysis also shows that the period 1995-1999 must be considered interim or a pilot phase (see also Section 3.2 below). Hence without major omissions and due to limitations in the data download dimensionality of the Local Databank most of the research presented here focuses on what is termed the roll-out and consolidation periods (1999-2014) (see also further below for a definition and discussion hereof). All variables except for the policy variable stems from the Polish Local Databank. The policy variable has been collected over several rounds. Initially the policy variable is based on published information about the areas affected by the zones policy in various consultant oriented publications from KPMG (e.g. KPMG, 2009, 20011). Finally, in 2015 primary data was collected directly from each zones administration (of which there are now 14 as named in Figure 1 above), the objective now being to specifically document the time dimension of when each area came into each of the 14 special economic zones managed by these individual zones administrations. The result of this data collection effort is also shown with Map 1.

\section{INSERT MAP $1 \mathrm{HERE}$}

\subsection{Main variables}

The main variables of interest is the outcome variable: employment; and the policy or treatment variable which consist in a time invariant dummy $S E Z_{i}$ (demarcating treated vs. non-treated areas without any specific time reference) and a matrix of time variant treatment dummies at the level of gminas (or LAU2 in 
Eurostat terminology $\left.{ }^{1}\right) W_{i t}$ (demarcting whether an area is currently in treatment or not). Compared to previous working papers and attempts to study the treatment effect, this paper solely focuses on the level of gminas (municipalities). This is important as treatment, while dispersed across Polish economic space (see Map 1), is very specifically confined to only affect certain economic areas (hence place-based) and by 2014 approximately $13 \%$ of all gminas are involved in the zones policy. The rest of the economic areas (or some of them) are used as counter factuals in order to estimate the average treatment effect. Given the cross-regional dispersion of the zones policy renders it near impossible to conduct evaluation of the employment effect of the policy at any other level of detail than the chosen. Already at the Poviat (LAU1) level more than $50 \%$ of the areas are affected by the policy. At the provincial (NUTS3) level there are only 3 provinces without any impact from the zones policy.

Employment in Table 1 is considered both as an absolute and relative variable, where the employment rate is defined in this study as employment over working age population ${ }^{2}$. The descriptive statistics confirm that the zones policy has targeted areas with higher employment and above average employment rates. The data in Table 1 also confirms that the policy has targeted urbanised areas with a relatively higher number of SOEs, but outside the major metropolitan areas which are not eligible to use incentives under the policy. While there is strong indication of selection on the SOE variable it does not lead to a complete separation between the treatment and control group and the difference is reduced over time as privatisation progresses (see also Table $5 \mathrm{~b}$ ).

In addition to the dependent variable (employment), several control variables are used in the study to control for area heterogeneity. These control variables are also listed in Table 1. The equality of means test (t-test) shows that on these various control variables, special economic zones do stand out as being special on almost every single aspect, notably a much higher population of firms and higher public spending on both education, infrastructure and public investment property. They are also much more likely to be located in gminas that are classified as urban (note that this variable is time invariant and therefore disappears into the fixed effects in the subsequent regressions). The only variable for which there was found to be no significant difference across areas with and without the zones policy, was on the investment outlays with firms.

The reported trend variables (pooled and panelled) in the last two columns of Table 1 demonstrate the persistence of these series generally for the pool and

\footnotetext{
${ }^{1}$ In the Eurostat NUTS (Nomenclature of Territorial Units for Statistics) classification there are three levels regulated by the European Union. For example, at the NUTS3 level the population size of an economic area is between 150,000 and 800,000. However, the LAU1 and LAU2 (formerly NUTS4 and NUTS5) is regulated individually by each country. In Poland the LAU2 level includes municipalities (gminas) varying in size from 300 to 43,000 permanent residents

${ }^{2}$ Note that the employment rate reported here greatly differs from official employment statistics that are based on participation rates measured using labour force surveys. The official employment rate is typically much higher as a large part of the working age population does not register as active in terms of participating in the labour force. This difference is not captured with the regional statistics available from the Polish Local Databank.
} 
specifically within the structured panel of gminas over time. For example, while employment is persistent over time in the pool, the panelled trend demonstrates that there is significant labour mobility across gminas taking place over the period of study. Employment and employment rate are; along with the share of land devoted to agriculture and EU subsidies per capita; among the least persistent variables in the panelled trend. Other variables such as government grants (subsidies) per capita and the population of private firms are highly persistent in their panelled trends.

INSERT TABLE 1 HERE

\subsection{Econometric strategy}

The econometric approach is a difference-in-difference estimator adjusted for the panel character of the data. The standard difference-in-difference framework requires two sets of observation over two periods (before and during policy treatment where the second period is represented with dummy $d 2$ ), for example, one set of economic areas (areas $B$ represented with dummy $B d B$ ) subject to policy treatment in the second period and another set of areas that are never subject to treatment (areas $A$ represented with the intercept):

$$
y=\beta_{0}+\beta_{1} d B+\delta_{0} d 2+\delta_{1} d 2 * d B+u \quad \text { (Eq. 1) }
$$

The panel setting is quite similar. The only difference being that there are more than two time periods and that policy treatment is something that happens continuously and gradually over time rather than in the discrete manner described in the two-by-two framework introduced above. Hence the equation to be estimated in a panel data setup translates into the following, the main difference being that covariates $X$ are introduced to control for heterogeneity and $W_{i t}$ is now a matrix of policy treatment dummies (replacing the ordinary treatment interaction effect in Equation $1 \delta_{1} d 2 * d B$ ) over time and take the value of one when the area is undergoing treatment (e.g. subject to the zones policy):

$E\left(y_{i t} \mid W_{i}, C_{i}, X_{i}\right)=C_{i 0}+\alpha_{0 t}+X_{i t} \beta_{0}+\tau_{0} W_{i t}+\varepsilon_{i t}, \quad t=1 \ldots T$, where $S E Z_{i} \in C_{i 0} \quad$ (Eq. 2)

The main caveats of this approach in a panel data setting is that there may be fundamental differences (or heterogeneity) among the economic areas that are not controlled for. Developments of each area over time may be due to third factors that are not controlled for but could be ascribed to the policy experiment. According to Wooldridge (2010, Page 904) this problem can be circumvented if many controls are used whereby the treatment becomes exogenous. Here a major advantage of panel data is that fixed effects together with a reasonable number of controls alleviates this problem. The procedure described in Wooldrige is followed whereby heterogeneity across treated and untreated areas is appropriately accounted for, e.g. introducing a separate effect for each control variable $X$ across treated and untreated areas using the mean difference deviation approach as suggested in Wooldridge (2010, Page 968): 
$E\left(y_{i t} \mid W_{i}, C_{i}, X_{i}\right)=C_{i 0}+\alpha_{0 t}+X_{i t} \beta_{0}+\tau_{0} W_{i t}+W_{i t}\left(X i t-\Psi_{t}\right)+\varepsilon_{i t}, \quad t=$ $1 \ldots T \quad S E Z_{i} \in C_{i 0}, \quad \Psi=E\left(X_{i t}\right)=\overline{X_{t}} \quad$ (Eq. 3)

A related problem concerns the selection bias which unlike heterogeneity takes an ex-ante character to the policy treatment and hence creates an endogeneity problem with respect to the interpretation of the parameter estimate for the policy variable. It is shown below with descriptive statistics that while the problem does exist that special economic zones are different from other areas in almost every respect (except for capital investment), this is true in particular for the selection variables of state owned enterprises and high employment areas (prone for future unemployment). The legal aspects of the zones policy also suggests that the main selection variable concerns the prior distribution of state owned enterprises and that special economic zones are more likely to be located in areas with a high concentration of SOEs prior to the speeding up of the privatisation process in 1998. Hence areas added later to the zones policy will be less prone for this selection bias compared to areas added relatively early in the history of the policy.

Two matching procedures are used to adjust for the selection bias. Due to King and Nielsen (2016) Mahalanobis distance matching on selected variables (in 1999) is chosen as the best procedure to reduce imbalance and model dependence. However, since the paper deals with population rather than sample data this standard matching procedure is complemented by a manual sample selection procedure that slices the data up similarly to the Mahalanobis matching procedure but without excluding outlier areas from the analysis. Besides the ordinary matrix of treatment dummies this can be expanded in different ways towards accounting for spatial and timing effects of the policy treatment. Initially the estimations include a spatial lag by constructing a spatial weighting matrix for the policy variable. This is done following the instructions in Drukker et al. (2013) through the creation of a contiguity matrix (or inverse distance matrix) using the shape file for the NTS5 level (obtained from the Central Statistical Office in Poland) and by connecting the output of the contiguity matrix with the information contained in the $W_{i t}$ variable. Hereby the spatial lag becomes a normalized representation (between 0 and 1) of whether an area is located in proximity to areas having implemented the zones policy and over time. This spatial lag is included in the original Equation 3. However, these results suggest that the spatial lag process could be driven by spillovers not at the outcome level of the policy (employment) but the policy level, e.g. areas adjacent to areas with the zones policy (as measured with the spatial lags) are much more likely to adopt the policy than other $\operatorname{areas}^{3}$. This indirect lag process present in the data therefore emphasises the importance of controlling for the timing aspect of the policy. For example, Wooldridge (2010, page 969) suggests to expand the matrix of treatment dummies into a $T x T$ matrix of treatment dum-

\footnotetext{
${ }^{3}$ Whereas the inclusion of the spatial lags based on the inverse distance matrix (not shown) give results that are more similar to those reported by Cizkowicz et al (2016), e.g. the spillover effect of the zones policy on employment is positive and relatively large, however, in this study remaining insignificant.
} 
mies. In view to the high number of $T$ in the present study a somewhat simpler approach is adopted to account for timing aspects of the policy treatment. A simple trend $(\varrho)$ is used where at the policy level the treatment dummies $\left(W_{i t}\right.$ 's) are simply interacted with a trend variable $t=1 . . T$ in the year of observations. Hereby is accounted for the year in the policy horizon that each area is treated: $\varrho_{i t}=W_{i t} * t \quad$ (Eq. 4$)$

Accounting for project level timing can also be subjected to a relatively simple trend, instead adopting a trend variable that varies at the level of each individual economic area treated with the number of years that the particular area has been in treatment:

$$
\vartheta_{i t}=\sum_{t=1}^{T} W_{i t} \quad \text { (Eq. 5) }
$$

These timing effects of the policy are added to Equation 3 individually and in combination.

\section{Regression results}

\subsection{Difference-in-difference base estimates}

Table 2 shows the results from applying the simple difference-in-difference estimator to the data without any covariates besides time dummies. Any heterogeneity existing across treated and untreated areas is captured with the area level dummy $\left(S E Z_{i}\right)$ which takes the value of 1 for all treated ares and is time invariant. These results confirm the descriptive statistics, that the areas with zones are generally quite special.

INSERT TABLE 2 HERE

Initial results for the main research question; being whether areas undergoing policy treatment do experience an improvement in employment levels over time; is answered with Table 2 showing that the average treatment effect is positive and significant although quite small (of around $3.9 \%$ on average ${ }^{4}$ ). Differences over the time horizon of the policy also confirm that the period 1995-1999 is a pilot phase, whereas the main effect of the policy is centred around the run-up to the EU accession in 2004 after which the effect of the policy starts to fade out or go into a different phase. The consolidation phase is also marked by a period where the EU structural funds start to take effect on regional development patterns in Poland. Here the focus is solely on the robustness of the results obtained with Table 2 as to there being a positive employment effect of the zones policy also taking into account dynamic aspects of the policy. The research now focuses on the period of the policy after it is rolled out in 1999 onwards.

\footnotetext{
${ }^{4}$ The exact effect for a semi-log regression when the dummy switches from 0 to 1 is $100(\exp (0.0378)-1)=3.9 \%$. The difference between the coefficient estimate and the exact effect is greater the greater the estimated coefficient. See also Giles (2011).
} 


\subsection{Introducing covariates into the difference-in-difference estimator}

In Table 3 the results are listed for the extended version of the basic differencein-difference estimator in Table 2 for panel data. Control is here made for general area heterogeneity adopting the approach suggested in Wooldridge as introduced earlier. Spatial lags are also included to test whether the zones policy has a positive or negative spillover effect on gminas bordering on the gminas that have adopted the zones policy.

INSERT TABLE 3 HERE

Table 3 shows that once area heterogeneity is addressed and only when it is accounted for across areas in and out of treatment, it increases the effect of being in treatment with a factor of around 6 (to around $24 \%$ on average in Column 4, Table 3). But the large differences across columns in Table 3 also suggest that results suffer from model dependence due to sample imbalances (King and Nielsen, 2016). The spatial lags based on the contiguity matrix are negative but insignificant (whereas those based on an inverse distance matrix are positive and relatively large but insignificant). This suggests that there may be a negative spillover effect from the policy on areas adjacent to the zones but that it does not run directly through the dependent variable (employment). A Granger causality test between the zones policy dummy and its spatial lag (based on the contiguity matrix) shows that causality runs from the lag to the zones policy rather than vice-versa. This confirms that if the policy has a spillover effect on neighbouring areas it takes place at the policy level. This can also explain why the spatial lags are insignificant. As new areas learn about the policy from neighboring areas they are more likely to adopt it. Hence any negative spillover effects on employment levels in gminas adjacent to gminas that have adopted the policy is likely to be preceded by the policy adoption effect.

\subsection{Introducing dynamic policy effects}

Table 4 expands on these results with respect to the more dynamic aspects of the treatment effect while maintaining the most salient covariates from Table 3 and also taking into account that some variables reduce the length of the panel especially in the beginning of the policy horizon. Therefore the two covariates 'infrastructure spending' and 'public investment property expenditure' are dropped from the analysis. Hereby the whole panel is maintained over the period 1999-2014 for further analysis.

INSERT TABLE 4 HERE

Two dynamic aspects of the policy are accounted for with the trended policy variables introduced in Table 4. As explained earlier the first variable accounts for the trend at the policy level by interacting the $S E Z$ time variant dummies (the Wit/s) with the general time trend over the policy horizon starting from the roll-out period (e.g. 1999-2014 where 1999 is trend=1, 2000 is trend=2 etc.).

Another similar variable is adopted at the project level, here accounting more specifically for the time that the policy has been active in each individual 
gmina. With these variables it is tested how the treatment effect changes with the the policy horizon at the policy or aggregate level of the zones policy and at the project level. The alternative would require to insert a matrix of $T x T$ or 256 dummy variables which has its limitations even cogently to report and summarize.

With the results in Table 4 it is observed that the employment effect of the policy does tend to wear out over time. The results demonstrate that timing is important to account for. Now the average treatment effect goes up to $116 \%$ but leveling out over time meaning that late adopters of the policy benefit on average less which is similar to a negative spillover effect at the policy level. While at the project level there is a positive learning effect on employment.

\subsection{Robustness check using sample matching}

Adding to the above results, Table 5A and 5B mainly serve as a robustness check yet moves to a rather crucial question in the research. Namely whether the results are robust to prior screening or the pre-selection criteria used for choosing areas eligible to participate in the policy. Owing to King and Nielsen (2016) the best approach to matching in this situation is Mahalanobis distance matching. This procedure is used in Table 5A whereby imbalance in the sample is reduced (e.g. some outlier areas disappear from the analysis and especially those that due to the slicing procedure are in the very high end of the distribution in terms of number of SOEs in 1999). The specific variables that were chosen to select the balanced sample are shown in the notes to Table 5A. These are chosen in a compromise between salience (e.g. more likely to be input rather than outcome related variables due to the policy) and not including too many or overlapping variables as the routine is also sensitive to the number of variables specified for the match. Exact matching is only possible on categorical variables such as the urban gmina dummies or close to categorical variables with a limited number of outcome possibilities such as number of SOEs. Both variables (employment and SOEs) are the most important inputs in the Mahalanobis matching procedure. Hereby we can see that the former discussed model dependence almost disappears and due to the matching procedure the results stabilise at an average treatment effect between 40-60\%.

INSERT TABLE 5A HERE

Alternatively and in view to that the present research concerns the population level and not a sample, one may argue that outliers are still relevant to account for in a broader understanding of treatment effects. To include outliers in the matching procedure a more manual approach is also taken but again slicing on the SOE variable. Here we have access to information about the prior distribution of SOEs in 1995 whereby it is also ensured that selection is on an ex-ante variable. Moving from the results for the full sample replicated from Table 4 with the first column in Table 5B; as we move towards the right, the sample compared becomes narrower and narrower as we increase the number of SOEs that were present in each area prior to selection or here documented with data from 1995. For example, the 2nd column shows results for all areas that 
had any SOEs and this process is continued until the two samples are almost identical in the third last column (or column 5). Here we compare outlier areas in Poland that had more than 25 SOEs in 1995 (of which there were 455 in the full sample out of which approximately half or 218 were in treatment).

INSERT TABLE 5B HERE

After column 5, areas in treatment (with Wit $=1$ ) start to take precedence in the sample and become almost the entire sample when the number of SOEs in 1995 goes to 100 and above. Therefore the policy effect waters out as there is nothing left to compare with at this level of outlier areas. Notice that the samples are reported in the last row of Table 5. For this uppper part of the population in terms of prior SOE distribution, the average treatment effect (captured with Wit) jumps now to $131 \%$ (see Footnote 3 ) while the levelling off effect in between the policy level and project level also increases now to around 3-4\% per year. Hence very narrowly comparing areas with a similar distribution of SOEs in 1995 with and without the policy, shows that the policy does have a quite large effect in terms of maintaining regional employment and especially in the areas that are the most vulnerable to transition and privatisation. Notice also here the wording of 'maintaining' rather than increasing since this is considered in fact more the result of the policy in a relatively stable national employment environment over the course of transition (see Table 2).

\section{Discussion and conclusion}

The objective of the paper is to evaluate the Polish special economic zones policy on its main objective which has been to sustain employment in areas that are more likely to suffer employment losses in economic transition. During the pilot phase the policy was largely unsuccessful and was under threat of becoming extinct. Turnaround started to happen in the roll-out phase (when there was a shift from a supply-led to a demand-led model of land development) and the desired results for employment took place in the consolidation phase now also aided by support from EU regional policy. A review of the legal foundations underlying the policy combined with practical outcomes and renegotiations with the EU about the zones policy demonstrate significant policy learning over time. Chance and opportunity in combination paved the way for a much more far reaching and gradual employment policy than anyone had envisioned at the beginning of the process back in 1994. While areas have been added to the policy over time, the main privilege, originally a full tax exemption, has been subject to a gradual and layered phasing out over time. As areas converge on the national income average, tax privileges will be phased out. Currently it is expected that the policy will loose its mandate in 2026 up from 2017 due to a recent renegotiation with the European Commission in 2013.

Given the main objective of the research the choice of methodology falls on a difference-in-difference estimator adjusted to a panel data setting. This method-

ology is extended to address area heterogeneity by inclusion of fixed effects and relevant covariates including spatial lags towards explaining the developments 
in regional employment over time. The spatial lags are insignificant but their inclusion leads to the finding that the spatial lags Granger cause the policy variable, meaning that the policy over time spreads more likely to gminas bordering on existing zones than any other areas. Inclusion is also made of policy trended variables seeking to address the dynamic aspects of policy outcomes over time thereby also shifting the interpretation of an average treatment effect and time invariant spatial lags in the study, to one that may show considerable variation both over the horizon of the policy itself and at the level of individual treatment of each area or policy 'project'. These results confirm the previous findings and show that as the policy spreads to adjacent areas there is some tendency for the effect on employment to level out across all treated areas. This would be similar to a negative spillover effect over time but captured in a somewhat different way.

Robustness checks using sample matching based on Mahalanobis mathcing and a more simple pre-selection criteria procedure similar to a pure match on the main screening variable (SOEs) are adopted. Reducing model dependence through sample balancing confirms an average treatment effect on the gminas (but excluding outliers from the population) at around $60 \%$. While a simpler manual matching approach also suggests that this effect may be as high as $130 \%$ at the high end of the distribution in terms of socialist production legacy of individual gminas.

These results are not out of line with some of the prior research that has been able to quite precisely document employment effects of place-based policies such as the study of the Tennessee Valley Authority by Moretti and Kline (2014). Outside the highly developed country context few studies are available that can offer as detailed a policy evaluation as this and other studies of the Polish context have been able to do. The main reason in the case of China is the problematic issue of accounting for employment effects when a policy relies so significantly on migrant labour. In other developing and transition country cases it has more to do with the barriers to getting as high quality and accurate data as we find it published in the Polish Local Databank. However, the literature review also shows how difficult it is to draw general lessons from comparing the headline results of many studies as there are a large number of underlying differences in methodologies, datasets, level of geographical detailedness and not least the theories that inform the studies and therefore also the hypothesis forming process. To draw more general lessons from the present study in relation to the greater literature on Special Economic Zones, it would be necessary to conduct a meta study where such differences are better accounted for. The comparison between this paper and the findings of Cizkowicz et al (2016) is a good case in point, as both the focus (direct vs. indirect or spillover effects), the theory perspectives (mainstream vs. political economy), the datasets (based on information that is collected at the centralised vs. decentralised levels) and the level of geographical detailedness (e.g. 379 counties vs. 3,829 municipalities) differ. Here it is proposed that the conclusions of the study by Cizkowicz et al (2016) could perhaps be too overtly positive as to the market-driven aspects of spillover processes associated with the policy due to the fact that it is difficult with that particular dataset and the specific perspective to account 
for the political-economy process which is taking place a the level of the zones administrations (now the focal points of public policy administration in Poland related with the SEZs and not the traditional local administrative authorities). The exact role of the zones administrations in creating the policy outocme is an important topic to be addressed in future research.

\section{References}

Aggarwal, A. (2007). Impact of Special Economic Zones on Employment, Poverty, and Human Development. New Delhi: Indian Council for Research on International Economic Relations.

Ambroziak, A. A. (2015). Income tax exemption as a regional state aid in special economic zones and its impact upon development of Polish districts (No. $38 / 2015)$.

Barca, F., McCann, P., \& Rodríguez-Pose, A. (2012). The case of regional development intervention: place-based versus place-neutral approaches. Journal of regional science, $52(1), 134-152$.

Biagi, F., Bondonio, D., \& Martini, A. (2015). Counterfactual Impact Evaluation of Enterprise Support Programmes. Evidence from a Decade of Subsidies to Italian Firm.

Busso, M., Gregory, J., \& Kline, P. M. (2010). Assessing the incidence and efficiency of a prominent place based policy (No. w16096). National Bureau of Economic Research.

Chaurey, R. (2014). Do location-based incentives promote industrialisation? Ideas for India for More Evidence-based Policy, September 232014. www.indeasforindia.in.

Cizkowicz, P., Cizkowicz-Pekala, M., Pekala, P. \& Rzonca, A. (2016). The effects of special economic zones on employment and investment: a spatial panel modeling perspective. Journal of Economic Geography, lbw028.

CoM.(2008a). On public aid granted to economic entities operating pursuant to a permit for carrying out busines activity within special economic zones. Regulation of the Council of Ministers of the Republic of Poland. December 10 2008.

CoM.(2008b). On criteria which need to be met to cover some lands by a special economic zone. Regulation of the Council of Ministers of the Republic of Poland. December 102008.

Drukker, D.M., Peng, H., Prucha, I. R., \& Raciborski, R. (2013). Creating and managing spatial-weighting matrices with the spmat command. Stata Journal, 13(2), 242-286.

Fertig, M., Schmidt, C. M., \& Schneider, H. (2006). Active labor market policy in Germany - Is there a successful policy strategy?. Regional Science and Urban Economics, 36(3), 399-430.

Giles, D. E. (2011). Interpreting dummy variables in semi-logarithmic regression models:Exact distributional results. University of Victoria Department of Economics Working Paper EWP No. 1101.

Givord, P., Rathelot, R., \& Sillard, P. (2013). Place-based tax exemptions and displacement effects: An evaluation of the Zones Franches Urbaines pro- 
gram. Regional Science and Urban Economics, 43(1), 151-163.

Grubel, H. G. (1982). Towards a theory of free economic zones. Weltwirtschaftliches Archiv, 118(1), 39-61.

Gwosdz, K., Jarczewski, W., Huculak, M., \& Wiederman, K. (2008). Polish special economic zones: idea versus practice. Environment and Planning C: Government and Policy, 26(4), 824-840.

Jensen, C., \& Winiarczyk, M. (2014). Special Economic Zones-20 years later. CASE Research Paper, (467).

King, G. \& Nielsen, R. (2016). Why propensity scores should not be used for matching. Copy at http://j. mp/1sexgVw Download Citation BibTex Tagged XML Download Paper, 378.

Kline, P. M., \& Moretti, E. (2014). Local economic development, agglomeration economies, and the big push: 100 years of evidence from the Tennessee Valley Authority Quarterly Journal of Economics. 275-331.

KPMG. (2009). A guide to special economic zones in Poland. KPMG in Poland.

KPMG. (2011). Special Economic Zones. KPMG in Poland.

KPMG (2013). Activity of Special Economic Zones has been extended until 2026. Official communication from KPMG in Poland.

Lechner, M., \& Wunsch, C. (2009). Active labour market policy in East Germany. Economics of Transition, 17(4), 661-702.

Levien, M. (2012). The land question: special economic zones and the political economy of dispossession in India. Journal of Peasant Studies, 39(3-4), 933-969.

Litwack, J.M. \& Qian, Y. (1998). Balanced or unbalanced development: special economic zones as catalysts for transition. Journal of Comparative Economics, 26(1), 117-141.

Martin, P., Mayer, T., \& Mayneris, F. (2011). Spatial concentration and plant-level productivity in France. Journal of Urban Economics, 69(2), 182195.

OJ (2007). Act of October 20th 1994 on special economic zones. Official Journal of Law no. 141.

OJ (2003). Act of 2 October 2003 on amendment to the act on the special economic zones and some acts. Official Journal of Law no. 188/2003 item 1840 (Journal of Laws of 5 November 2003) with subsequent amendments.

OJ (2008). Act of 30 May 2008 on the amendments to the Act on special economic zones. Official Journal of Laws no. 118. Item 746.

Papke, L. E. (1994). Tax policy and urban development: evidence from the Indiana enterprise zone program. Journal of Public Economics, 54(1), 37-49.

Park, B. G. (2005). Spatially selective liberalization and graduated sovereignty: Politics of neo-liberalism and "special economic zones" in South Korea. Political Geography, 24(7), 850-873.

Rasiah, R., \& Shari, I. (2001). Market, government and Malaysia's new economic policy. Cambridge Journal of Economics, 25(1), 57-78.

Rodrik, D. (2008). Second-Best Institutions. The American Economic Review, 98(2), 100-104. 
Westphal, L.E. (1990). Industrial policy in an export propelled economy: lessons from South Korea's experience. The Journal of Economic Perspectives, $4(3), 41-59$.

Wang, J. (2013). The economic impact of special economic zones: Evidence from Chinese municipalities. Journal of development economics, 101, 133-147.

Wooldridge, J. M. (2010). Econometric analysis of cross section and panel data. MIT press.

Yeung, Y. M., Lee, J., \& Kee, G. (2009). China's special economic zones at 30. Eurasian Geography and Economics, 50(2), 222-240.

Zheng, S., Sun, W., Wu, J. \& Kahn, M.E. (2015). The Birth of Edge Cities in China:Measuring the Spillover Effects of Industrial Parks. Working Paper No. w21378. National Bureau of Economic Research. 


\section{Special Economic Zones}

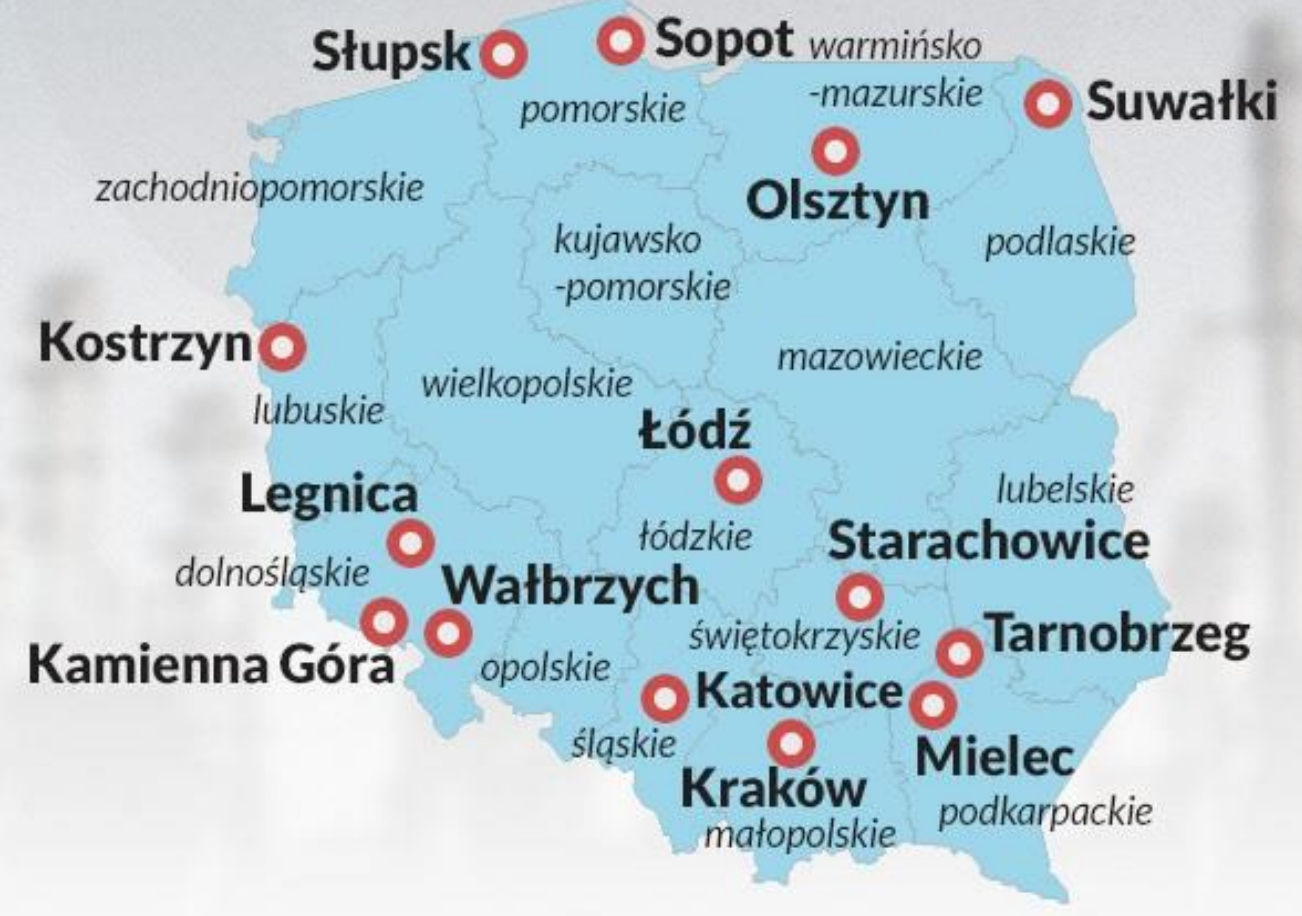

Map 1 - Headquarters of each Special Economic Zones' administration 


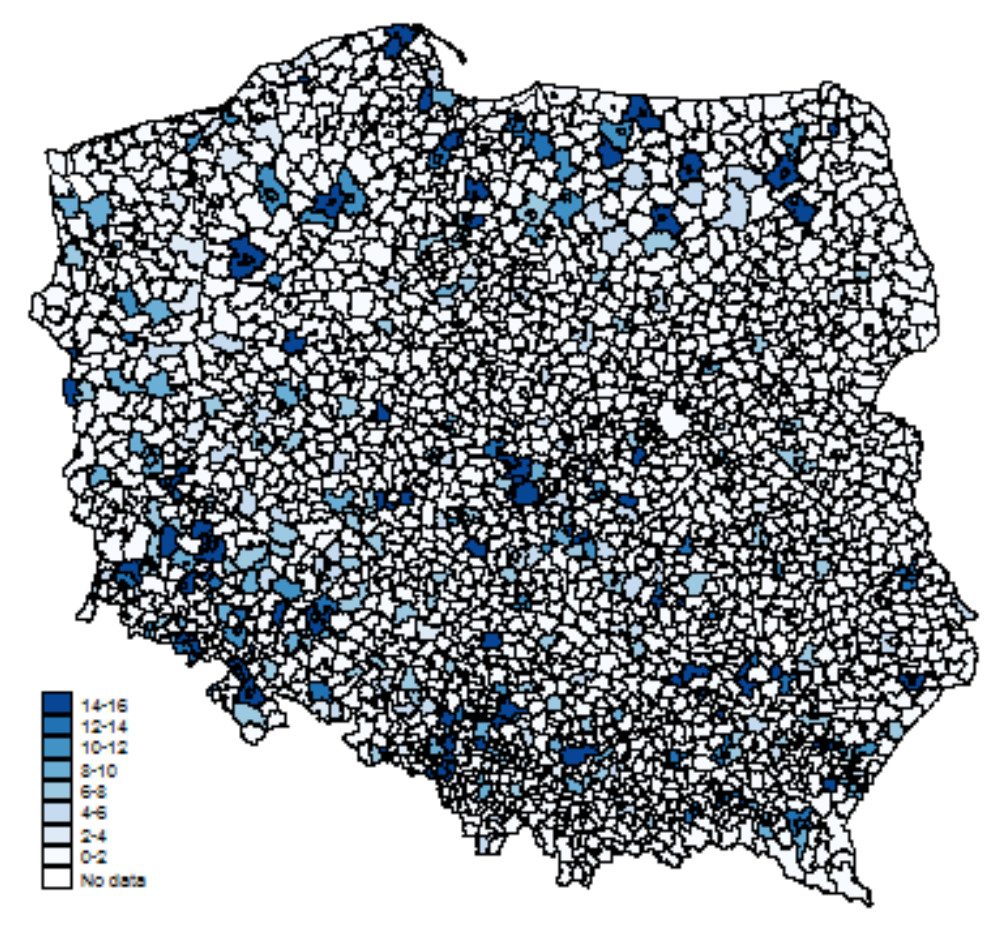

Map 2 - Number of years that the policy affected areas (municipalities) have been in treatment 

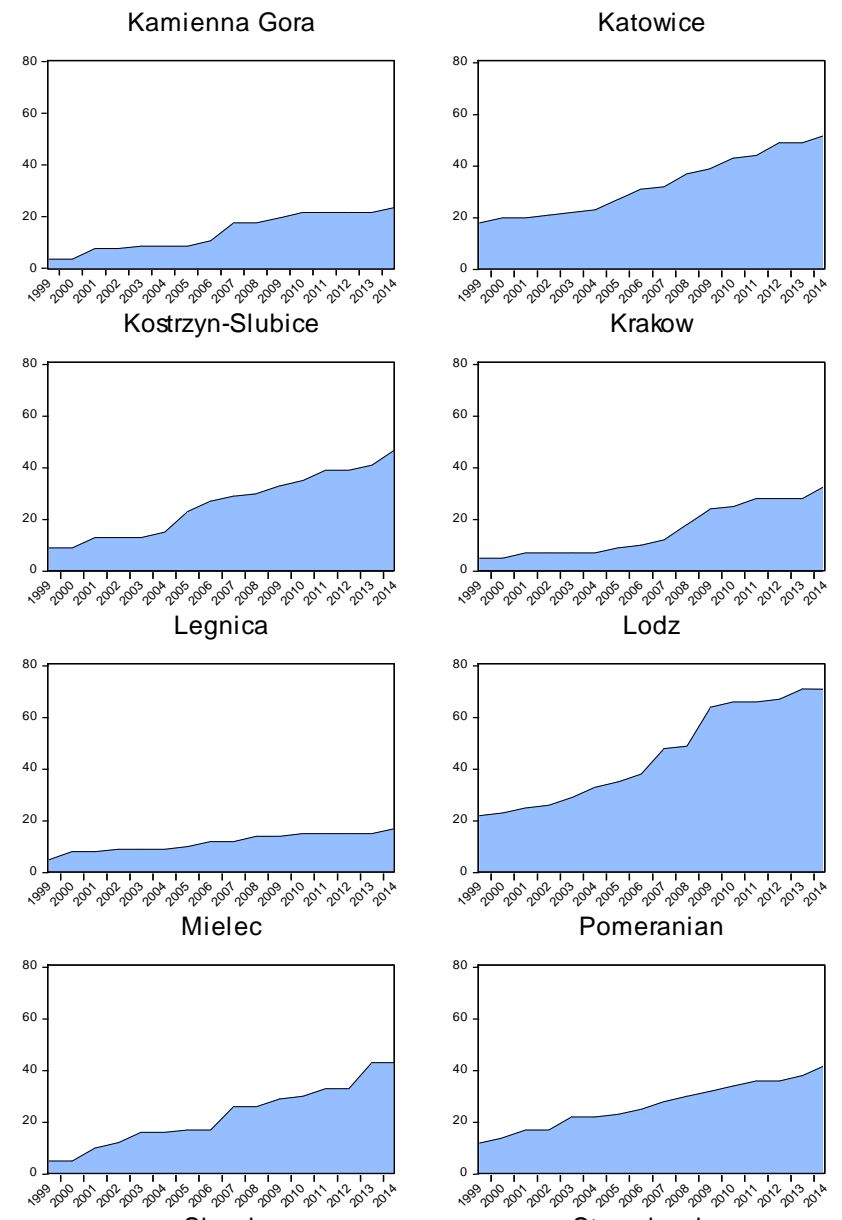

Starachowice

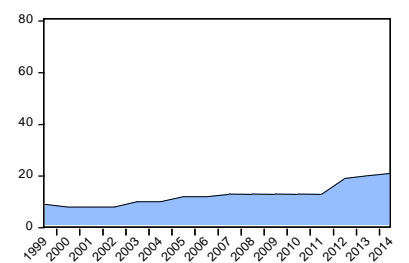

Suwalk

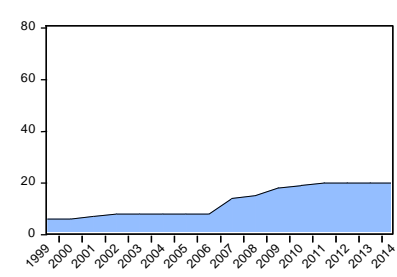

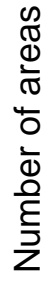

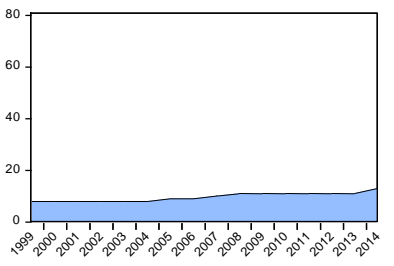

Tarnobrzeg

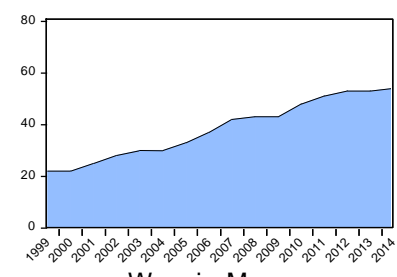

Warmia-Mazury
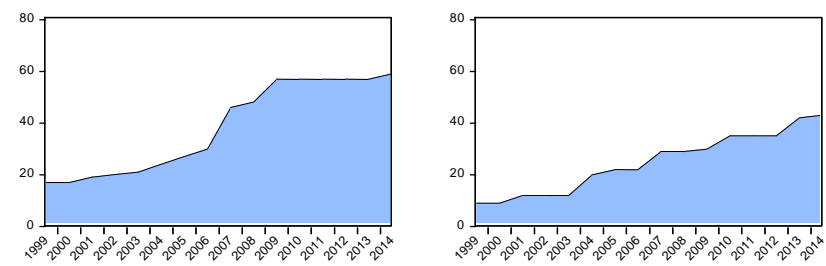

Year

FIGURE 1 - Number of areas treated by each Special Economic Zones' administration over time 
Number of SOEs per area

categ orised by year and treatment status
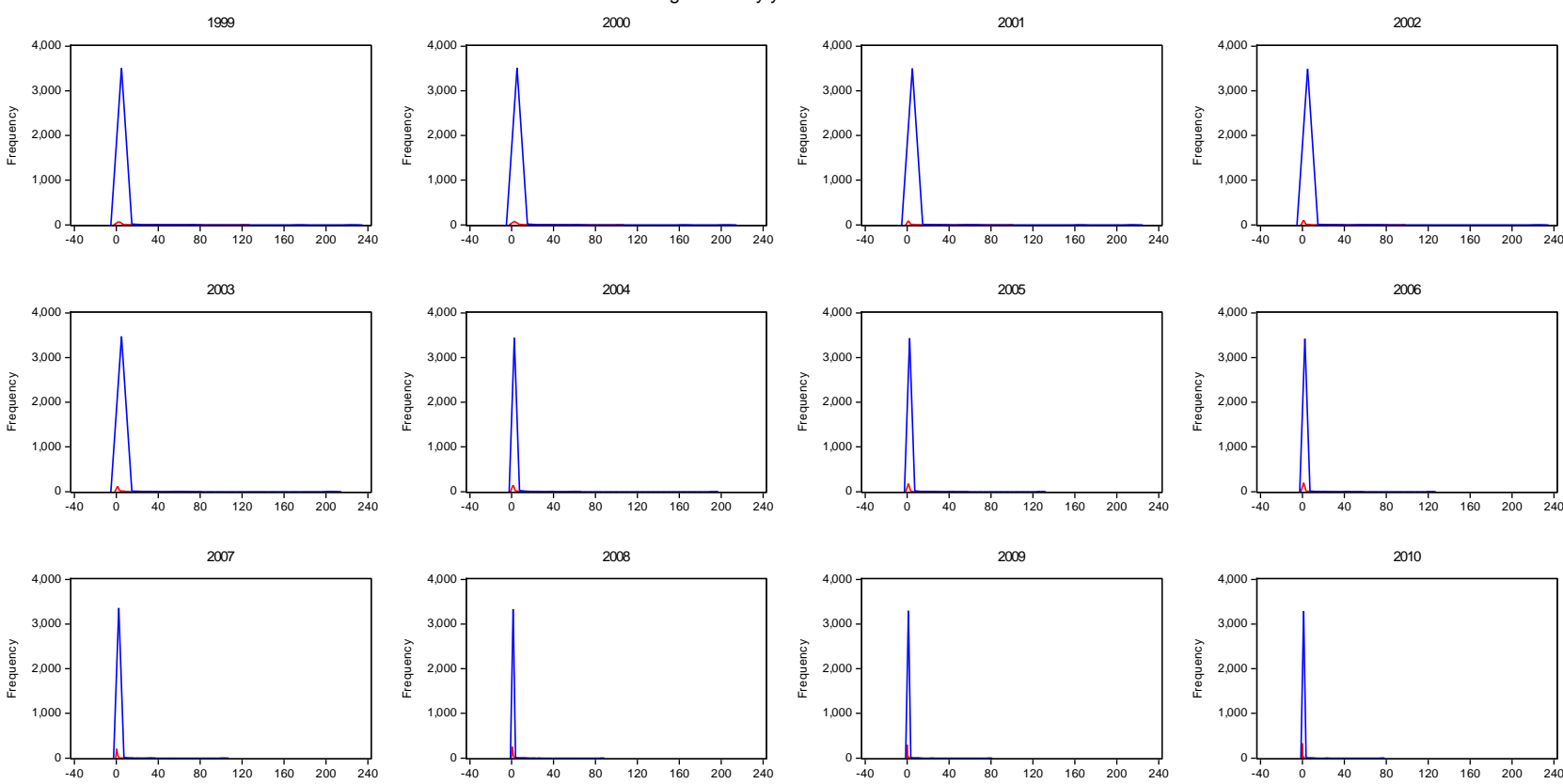

2008
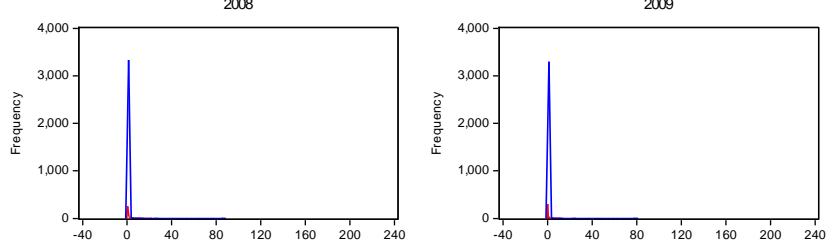

2010

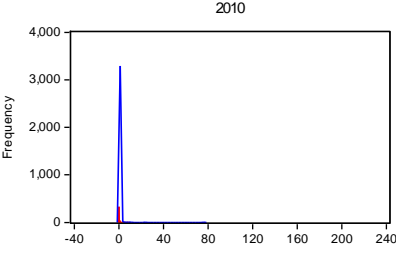

2012
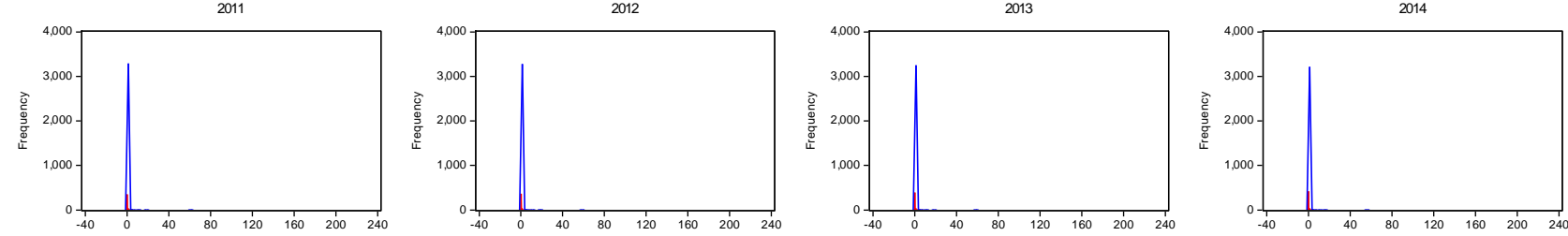

— Areas out of treatment

_ Areas undergoing treatment

Figure 2 - Histograms for the distribution of SOEs per area in and out of treatment and over time 


\begin{tabular}{|c|c|c|c|c|c|c|c|}
\hline \multirow{2}{*}{$\begin{array}{l}\text { Variable } \\
\text { Population/subsets: }\end{array}$} & \multirow{2}{*}{$\begin{array}{l}\begin{array}{l}\text { Mean value } \\
\text { for all areas } \\
i\end{array} \\
\mathrm{~N}=58,679^{\mathrm{b}}\end{array}$} & \multicolumn{2}{|c|}{$\begin{array}{l}\text { Mean value for treated } \\
\text { areas }\left(S E Z_{i}\right)\end{array}$} & \multicolumn{2}{|c|}{$\begin{array}{l}\text { Mean value for areas in } \\
\text { treatment }\left(W_{i t}\right)\end{array}$} & \multicolumn{2}{|c|}{$\begin{array}{l}\text { Trend } t \\
\left(y_{i t}=c+t * y_{i t-1}\right)\end{array}$} \\
\hline & & $\begin{array}{l}\text { Never } \\
\text { treated } \\
\mathrm{n}=51,161\end{array}$ & $\begin{array}{l}\text { Treated } \\
\mathrm{n}=7,518\end{array}$ & $\begin{array}{l}\text { Out of } \\
\text { treatment } \\
\mathrm{n}=54,415\end{array}$ & $\begin{array}{l}\text { In } \\
\text { treatment } \\
\mathrm{n}=4,264\end{array}$ & Pooled & Paneled \\
\hline Employment (no. of) & 2,819 & 1,656 & $10,735 * * *$ & 2,097 & $12,041 * * *$ & 1.00 & 0.43 \\
\hline $\begin{array}{l}\text { Employment rate } \\
\text { (employment over } \\
\text { working age population) }\end{array}$ & 0.21 & 0.18 & $0.32 * * *$ & 0.20 & $0.33 * * *$ & 0.93 & 0.58 \\
\hline SOEs (no. of) & 0.36 & 0.22 & $1.32 * * *$ & 0.31 & $0.90 * * *$ & 0.89 & 0.86 \\
\hline Foreign firms (no. of) & 23 & 17 & $61 * * *$ & 19 & $74 * * *$ & 1.06 & 1.10 \\
\hline Private firms (no. of) & 1,232 & 808 & $4,117 * * *$ & 967 & $4,619 * * *$ & 1.02 & 0.98 \\
\hline $\begin{array}{l}\text { Share of area used for } \\
\text { agriculture }\end{array}$ & 0.60 & 0.60 & $0.54 * * *$ & 0.60 & $0.54 * * *$ & 0.99 & 0.59 \\
\hline $\begin{array}{l}\text { Education expenditure } \\
\text { per capita (zl) }\end{array}$ & 580 & 548 & $798 * * *$ & 555 & $900 * * *$ & 1.02 & 0.75 \\
\hline $\begin{array}{l}\text { Infrastructure expenditure } \\
\text { per capita }(\mathrm{zl})^{\mathrm{c}}\end{array}$ & 136 & 123 & $229 * * *$ & 125 & $267 * * *$ & 0.72 & 0.34 \\
\hline $\begin{array}{l}\text { Government grants per } \\
\text { capita }(\mathrm{zl})\end{array}$ & 568 & 557 & $645 * * *$ & 557 & $701 * * *$ & 1.03 & 0.89 \\
\hline $\begin{array}{l}\text { EU subsidies per capita } \\
(\mathrm{zl})^{\mathrm{e}}\end{array}$ & 16.31 & 15.09 & $24.57 * * *$ & 15.04 & $32.49 * * *$ & 0.28 & 0.16 \\
\hline $\begin{array}{l}\text { Investment outlays (mio } \\
\text { zl) }\end{array}$ & 261 & 263 & 249 & 259 & 286 & 1.02 & 0.75 \\
\hline $\begin{array}{l}\text { Public investment } \\
\text { property expenditure } \\
(\text { mio } \mathrm{zl})\end{array}$ & 5.4 & 3.1 & $21 * * *$ & 3.7 & $27.2 * * *$ & 1.01 & 0.78 \\
\hline $\begin{array}{l}\text { Monthly gross wages } \\
(\mathrm{zl})^{\mathrm{d}}\end{array}$ & 2,545 & 2,539 & $2,592 * * *$ & 2,524 & $2,786 * * *$ & 1.02 & 0.81 \\
\hline $\begin{array}{l}\text { Tax contribution to } \\
\text { central budget per firm } \\
\text { (zl) }\end{array}$ & 121 & 86 & $357 * * *$ & 95 & $444 * * *$ & 0.87 & 0.59 \\
\hline Urban gmina dummy & 0.09 & 0.04 & $0.35 * * *$ & 0.06 & $0.37 * * *$ & - & - \\
\hline \multicolumn{8}{|c|}{$\begin{array}{l}\text { NOTES: Significance of mean difference for the t-test: }{ }^{*} p<0.05,{ }^{* *} p<0.01,{ }^{* * *} p<0.001 \\
\text { a/ The reported means refers to the grand means over the full period of study (1999-2014). See also note b. } \\
\text { b/ Population totals refer to variables recorded across all years and at the NTS5 level (Lau2), c and d excepted. } \\
\text { c/ This variable is only available from } 2001 \text { onwards. } \\
\text { d/ This variable is only available from } 2002 \text { onwards at the NTS4 level. } \\
\text { e/ The variable is available throughout the period of study, but only takes effect/meaning from } 2006 \text { onwards after } \\
\text { Poland is included in the EU Structural Funds. }\end{array}$} \\
\hline
\end{tabular}

Table 1 - Descriptive statistics (mean values) and equality of means tests by area and policy variable, 19992014 


\begin{tabular}{lcccc}
\hline Dep.var. & $(1)$ & $(2)$ & $(3)$ & $(4)$ \\
Log Employment & $1995-2014$ & $1999-2014$ & $2006-2014$ & $2009-2014$ \\
\hline Constant & $6.6112^{* * *}$ & $6.5585^{* * *}$ & $6.4307^{* * * *}$ & $6.4901^{* * * *}$ \\
& $(0.0188)$ & $(0.0193)$ & $(0.0198)$ & $(0.0199)$ \\
$\mathrm{SEZ}$ & $1.6619^{* * * *}$ & $1.6640^{* * *}$ & $1.7140^{* * *}$ & $1.7230^{* * * *}$ \\
& $(0.0689)$ & $(0.0692)$ & $(0.0690)$ & $(0.0688)$ \\
$\mathrm{W}_{\text {it }}$ & $0.0352^{*}$ & $0.0378^{* *}$ & 0.0092 & 0.0014 \\
& $(0.0138)$ & $(0.0133)$ & $(0.0108)$ & $(0.0128)$ \\
Year fixed effects & Yes $^{* * *}$ & Yes $^{* * *}$ & Yes & Yes**** \\
\hline Number of obs. & 70,756 & 56,349 & 33,177 & 22,185 \\
$\mathrm{R}^{2}$ overall & 0.1988 & 0.1967 & 0.1904 & 0.1910 \\
$\mathrm{R}^{2}$ between & 0.1831 & 0.1803 & 0.1912 & 0.1916 \\
$\mathrm{R}^{2}$ within & 0.1203 & 0.0953 & 0.0683 & 0.0493 \\
Sigma u & 1.1290 & 1.1512 & 1.1557 & 1.1590 \\
Sigma eit & 0.2162 & 0.1971 & 0.1502 & 0.1193 \\
Rho & 0.9646 & 0.9715 & 0.9834 & 0.9895 \\
\hline
\end{tabular}

Clustered robust standard errors in parentheses

${ }^{*} p<0.05,{ }^{* *} p<0.01,{ }^{* * *} p<0.001$

Table 2 - Difference-in-difference estimates translated into a panel data setting with continuous time 


\begin{tabular}{|c|c|c|c|c|c|c|}
\hline Dep. var.: & (1) & (2) & (3) & (4) & (5) & (6) \\
\hline Log Employment & $\mathrm{DiD}+\mathrm{fe}+\mathrm{cv}$ & $\mathrm{DiD}+\mathrm{fe}+\mathrm{cv}$ & $\mathrm{DiD}+\mathrm{fe}+\mathrm{cv}$ & $\mathrm{DiD}+\mathrm{fe}+\mathrm{cv}$ & $\mathrm{DiD}+\mathrm{fe}+\mathrm{cv}$ & $\mathrm{DiD}+\mathrm{fe}+\mathrm{cv}$ \\
\hline Constant & $\begin{array}{l}5.8418^{* * *} \\
(0.9366)\end{array}$ & $\begin{array}{c}6.0471^{* * * *} \\
(0.9414)\end{array}$ & $\begin{array}{c}6.4180^{* * * *} \\
(0.9019)\end{array}$ & $\begin{array}{c}6.4157^{* * * *} \\
(0.9182)\end{array}$ & $\begin{array}{c}18.7081^{* * *} \\
(1.1490)\end{array}$ & $\begin{array}{c}19.0142^{* * * *} \\
(1.1482)\end{array}$ \\
\hline Wit & $\begin{array}{c}-0.1577^{* * * *} \\
(0.0250)\end{array}$ & $\begin{array}{l}0.2059^{* * *} \\
(0.0708)\end{array}$ & $\begin{array}{c}-0.1386^{* * * *} \\
(0.0234)\end{array}$ & $\begin{array}{c}0.2168^{* * * *} \\
(0.0646)\end{array}$ & $\begin{array}{c}-0.2216^{* * *} \\
(0.0269)\end{array}$ & $\begin{array}{c}0.1731 \\
(0.1159)\end{array}$ \\
\hline Spatial lag of Wit ${ }^{\mathrm{a}}$ & $\begin{array}{l}-0.0608 \\
(0.3904)\end{array}$ & $\begin{array}{l}-0.0114 \\
(0.3926)\end{array}$ & $\begin{array}{l}-0.0811 \\
(0.3908)\end{array}$ & $\begin{array}{l}-0.0425 \\
(0.3927)\end{array}$ & $\begin{array}{l}-0.6584 \\
(0.3924)\end{array}$ & $\begin{array}{l}-0.6152 \\
(0.3946)\end{array}$ \\
\hline Log Working Age Population & $\begin{array}{c}0.7752^{* * * *} \\
(0.1300)\end{array}$ & $\begin{array}{l}0.7410^{* * * *} \\
(0.1308)\end{array}$ & $\begin{array}{c}0.6966^{* * *} \\
(0.1253)\end{array}$ & $\begin{array}{c}0.6905^{* * *} \\
(0.1275)\end{array}$ & $\begin{array}{l}1.1104^{* * *} \\
(0.1563)\end{array}$ & $\begin{array}{l}1.0627^{* * * *} \\
(0.1559)\end{array}$ \\
\hline Deviation for Wit & - & $\begin{array}{l}-0.2686^{*} \\
(0.1138)\end{array}$ & - & $\begin{array}{c}-0.1892 \\
(0.1124)\end{array}$ & - & $\begin{array}{l}-0.2085 \\
(0.1353)\end{array}$ \\
\hline Log SOEs & $\begin{array}{c}-0.0637^{* *} \\
(0.0247)\end{array}$ & $\begin{array}{c}-0.1103^{* * *} \\
(0.0305)\end{array}$ & - & - & $\begin{array}{l}-0.0118 \\
(0.0307)\end{array}$ & $\begin{array}{l}-0.0625 \\
(0.0385)\end{array}$ \\
\hline Deviation for Wit & - & $\begin{array}{c}0.2274^{* * * *} \\
(0.0448)\end{array}$ & - & - & - & $\begin{array}{l}0.1878^{* * * *} \\
(0.0495)\end{array}$ \\
\hline Log Firms & $\begin{array}{c}0.1226^{*} \\
(0.0596)\end{array}$ & $\begin{array}{c}0.1148 \\
(0.0598)\end{array}$ & $\begin{array}{c}0.1215^{*} \\
(0.0596)\end{array}$ & $\begin{array}{c}0.1139 \\
(0.0599)\end{array}$ & $\begin{array}{c}0.1641^{*} \\
(0.0698)\end{array}$ & $\begin{array}{l}0.1561^{*} \\
(0.0702)\end{array}$ \\
\hline Deviation for Wit & - & $\begin{array}{c}0.2516^{*} \\
(0.1049)\end{array}$ & - & $\begin{array}{l}0.2748^{* *} \\
(0.1052)\end{array}$ & - & $\begin{array}{c}0.2553^{*} \\
(0.1174)\end{array}$ \\
\hline Log Foreign Firms & $\begin{array}{c}0.0513^{*} \\
(0.0226)\end{array}$ & $\begin{array}{c}0.0548^{*} \\
(0.0228)\end{array}$ & $\begin{array}{c}0.0563^{*} \\
(0.0225)\end{array}$ & $\begin{array}{l}0.0593^{* *} \\
(0.0227)\end{array}$ & $\begin{array}{c}0.0506^{*} \\
(0.0243)\end{array}$ & $\begin{array}{l}0.0574^{*} \\
(0.0245)\end{array}$ \\
\hline Deviation for Wit & - & $\begin{array}{l}-0.0420 \\
(0.0289)\end{array}$ & - & $\begin{array}{l}-0.0393 \\
(0.0295)\end{array}$ & - & $\begin{array}{l}-0.0672^{*} \\
(0.0327)\end{array}$ \\
\hline Log Education Expenditure & $\begin{array}{c}-0.6161^{* * * *} \\
(0.0202)\end{array}$ & $\begin{array}{c}-0.6034^{* * * *} \\
(0.0203)\end{array}$ & $\begin{array}{c}-0.6097^{* * * *} \\
(0.0200)\end{array}$ & $\begin{array}{c}-0.6009^{* * * *} \\
(0.0201)\end{array}$ & $\begin{array}{c}-0.2620^{* * * *} \\
(0.0371)\end{array}$ & $\begin{array}{c}-0.2244^{* * * *} \\
(0.0385)\end{array}$ \\
\hline Deviation for Wit & - & $\begin{array}{c}-0.0793^{* * *} \\
(0.0152)\end{array}$ & - & $\begin{array}{c}-0.0838^{* * * *} \\
(0.0137)\end{array}$ & - & $\begin{array}{c}-0.3313^{* * * *} \\
(0.0787)\end{array}$ \\
\hline Log Government Grants & - & - & - & - & $\begin{array}{c}-1.8320^{* * *} \\
(0.0492)\end{array}$ & $\begin{array}{c}-1.8568^{* * *} \\
(0.0499)\end{array}$ \\
\hline Deviation for Wit & - & - & - & - & & $\begin{array}{c}0.2700^{* * * *} \\
(0.0754)\end{array}$ \\
\hline Log Infrastructure Spending & - & - & - & - & $\begin{array}{c}-0.0437^{* * *} \\
(0.0070)\end{array}$ & $\begin{array}{c}-0.0420^{* * * *} \\
(0.0072)\end{array}$ \\
\hline Deviation for Wit & - & - & - & - & - & $\begin{array}{l}-0.0159 \\
(0.0224)\end{array}$ \\
\hline Log Public Property Inv. Exp. & - & - & - & - & $\begin{array}{c}-0.0345^{* * * *} \\
(0.0078)\end{array}$ & $\begin{array}{c}-0.0354^{* * * *} \\
(0.0082)\end{array}$ \\
\hline Deviation for Wit & - & - & - & - & & $\begin{array}{c}-0.0007 \\
(0.0253)\end{array}$ \\
\hline Year fixed effects & Yes $^{* * *}$ & Yes $^{* * *}$ & Yes ${ }^{* * *}$ & Yes ${ }^{* * * *}$ & Yes $^{* * * *}$ & Yes ${ }^{* * * *}$ \\
\hline Number of obs. & 58,647 & 58,647 & 58,647 & 58,647 & 51,399 & 51,399 \\
\hline $\mathrm{R}^{2}$ overall & 0.0203 & 0.0210 & 0.0216 & 0.0211 & 0.0675 & 0.0682 \\
\hline $\mathrm{R}^{2}$ between & 0.0765 & 0.0794 & 0.0805 & 0.0798 & 0.1515 & 0.1531 \\
\hline $\mathrm{R}^{2}$ within & 0.3193 & 0.3198 & 0.3192 & 0.3195 & 0.3562 & 0.3567 \\
\hline Sigma $u_{i}$ & 4.9851 & 4.9130 & 4.9564 & 4.9018 & 16.4651 & 16.3859 \\
\hline Sigma $e_{i t}$ & 1.0695 & 1.0692 & 1.0696 & 1.0694 & 1.1023 & 1.1019 \\
\hline Rho & 0.9560 & 0.9548 & 0.9555 & 0.9546 & 0.9955 & 0.9955 \\
\hline
\end{tabular}

Notes: Clustered robust standard errors in parentheses ${ }^{*} p<0.05,{ }^{* *} p<0.01,{ }^{* * *} p<0.001$

a/Granger causality test (with 2 lags):

\begin{tabular}{lrrr}
\hline \hline Null Hypothesis: & Obs & F-Statistic & Prob. \\
\hline \hline Spatial lag of Wit does not Granger Cause Wit & 53606 & 10.3964 & $3 . E-05$ \\
Wit does not Granger Cause Spatial lag of Wit & & 1.29181 & 0.2748 \\
\hline \hline
\end{tabular}

Table 3 - Difference-in-difference estimates with covariates, spatial lags of Wit and correction for heterogeneity across treated and untreated areas 


\begin{tabular}{|c|c|c|c|c|c|}
\hline Dep. var.: & (1) & (2) & (3) & (4) & (5) \\
\hline Log Employment & $\mathrm{DiD}+\mathrm{fe}+\mathrm{vc}$ & $\mathrm{DiD}+\mathrm{fe}+\mathrm{vc}$ & $\mathrm{DiD}+\mathrm{fe}+\mathrm{vc}+\mathrm{dpt}$ & $\mathrm{DiD}+\mathrm{fe}+\mathrm{vc}+\mathrm{dpt}$ & $\mathrm{DiD}+\mathrm{fe}+\mathrm{vc}+\mathrm{dpt}$ \\
\hline Constant & $\begin{array}{c}7.0344 * * * \\
(0.9625)\end{array}$ & $\begin{array}{c}7.2177 * * * \\
(0.9649)\end{array}$ & $\begin{array}{c}7.2812 * * * \\
(0.9678)\end{array}$ & $\begin{array}{c}7.2343 * * * \\
(0.9657)\end{array}$ & $\begin{array}{c}\text { 7.3157**** } \\
(0.9672)\end{array}$ \\
\hline Wit & $\begin{array}{c}-0.1620^{* * * *} \\
(0.0244)\end{array}$ & $\begin{array}{l}0.2031^{* *} \\
(0.0694)\end{array}$ & $\begin{array}{c}0.4282^{* * * *} \\
(0.0845)\end{array}$ & $\begin{array}{l}0.2192^{* * *} \\
(0.0724)\end{array}$ & $\begin{array}{c}0.7699^{* * * *} \\
(0.0887)\end{array}$ \\
\hline Wit*t & - & - & $\begin{array}{c}-0.0222 * * * \\
(0.0039)\end{array}$ & - & $\begin{array}{c}-0.0641 * * * \\
(0.0061)\end{array}$ \\
\hline Wit*ti & - & - & - & $\begin{array}{c}-0.0091^{* *} \\
(0.0032)\end{array}$ & $\begin{array}{c}0.0470 * * * \\
(0.0053)\end{array}$ \\
\hline Log Working Age Population & $\begin{array}{c}0.8079^{* * * *} \\
(0.1290)\end{array}$ & $\begin{array}{c}0.7711^{* * *} \\
(0.1297)\end{array}$ & $\begin{array}{c}0.7475^{* * * *} \\
(0.1302)\end{array}$ & $\begin{array}{c}0.7630^{* * * *} \\
(0.1299)\end{array}$ & $\begin{array}{l}0.7450^{* * * *} \\
(0.1301)\end{array}$ \\
\hline Deviation for Wit & - & $\begin{array}{c}-0.1678 \\
(0.1146)\end{array}$ & $\begin{array}{c}-0.1673 \\
(0.1126)\end{array}$ & $\begin{array}{c}-0.1674 \\
(0.1157)\end{array}$ & $\begin{array}{c}-0.1685 \\
(0.1060)\end{array}$ \\
\hline Log SOEs & $\begin{array}{l}-0.0369 \\
(0.0258)\end{array}$ & $\begin{array}{c}-0.0823^{* *} \\
(0.0317)\end{array}$ & $\begin{array}{c}-0.0859^{* * *} \\
(0.0318)\end{array}$ & $\begin{array}{c}-0.0846^{* * *} \\
(0.0319)\end{array}$ & $\begin{array}{l}-0.0808^{*} \\
(0.0317)\end{array}$ \\
\hline Deviation for Wit & - & $\begin{array}{c}0.2220 * * * \\
(0.0454)\end{array}$ & $\begin{array}{c}0.1476 * * \\
(0.0485)\end{array}$ & $\begin{array}{c}0.1934 * * * \\
(0.0482)\end{array}$ & $\begin{array}{c}0.1548 * * \\
(0.0475)\end{array}$ \\
\hline Log Firms & $\begin{array}{c}0.1095 \\
(0.0588)\end{array}$ & $\begin{array}{c}0.1058 \\
(0.0591)\end{array}$ & $\begin{array}{c}0.1088 \\
(0.0591)\end{array}$ & $\begin{array}{c}0.1073 \\
(0.0591)\end{array}$ & $\begin{array}{c}0.1066 \\
(0.0591)\end{array}$ \\
\hline Deviation for Wit & - & $\begin{array}{c}0.1835 \\
(0.1059)\end{array}$ & $\begin{array}{c}0.1772 \\
(0.1023)\end{array}$ & $\begin{array}{c}0.1806 \\
(0.1061)\end{array}$ & $\begin{array}{c}0.1802 \\
(0.0960)\end{array}$ \\
\hline Log Foreign Firms & $\begin{array}{c}0.0444^{*} \\
(0.0224)\end{array}$ & $\begin{array}{c}0.0486^{*} \\
(0.0226)\end{array}$ & $\begin{array}{c}0.0502^{*} \\
(0.0227)\end{array}$ & $\begin{array}{c}0.0493^{*} \\
(0.0226)\end{array}$ & $\begin{array}{c}0.0496^{*} \\
(0.0226)\end{array}$ \\
\hline Deviation for Wit & - & $\begin{array}{c}-0.0542 \\
(0.0296)\end{array}$ & $\begin{array}{c}-0.0505 \\
(0.0290)\end{array}$ & $\begin{array}{l}-0.0498 \\
(0.0297)\end{array}$ & $\begin{array}{l}-0.0662^{*} \\
(0.0276)\end{array}$ \\
\hline Log Education Expenditure & $\begin{array}{c}-0.3771^{* * *} \\
(0.0664)\end{array}$ & $\begin{array}{c}-0.3723^{* * * *} \\
(0.0693)\end{array}$ & $\begin{array}{c}-0.3644^{* * * * *} \\
(0.0688)\end{array}$ & $\begin{array}{c}-0.3689^{* * * *} \\
(0.0692)\end{array}$ & $\begin{array}{c}-0.3671^{* * * *} \\
(0.0686)\end{array}$ \\
\hline Deviation for Wit & - & $\begin{array}{l}-0.0092 \\
(0.0816)\end{array}$ & $\begin{array}{c}0.0378 \\
(0.0820)\end{array}$ & $\begin{array}{c}0.0078 \\
(0.0819)\end{array}$ & $\begin{array}{c}0.0393 \\
(0.0819)\end{array}$ \\
\hline Log Government Grants & $\begin{array}{c}-0.3756^{* * *} \\
(0.0985)\end{array}$ & $\begin{array}{c}-0.3659^{* * * *} \\
(0.1007)\end{array}$ & $\begin{array}{c}-0.3631^{* * * *} \\
(0.0999)\end{array}$ & $\begin{array}{c}-0.3652^{* * * *} \\
(0.1005)\end{array}$ & $\begin{array}{c}-0.3613^{* * * *} \\
(0.0996)\end{array}$ \\
\hline Deviation for Wit & - & $\begin{array}{c}-0.0737 \\
(0.0824)\end{array}$ & $\begin{array}{c}-0.1114 \\
(0.0824)\end{array}$ & $\begin{array}{c}-0.0871 \\
(0.0825)\end{array}$ & $\begin{array}{l}-0.1133 \\
(0.0825)\end{array}$ \\
\hline Year fixed effects & Yes $^{* * *}$ & $\mathrm{Yes}^{* * *}$ & Yes $^{* * *}$ & Yes ${ }^{* * *}$ & Yes $^{* * *}$ \\
\hline $\mathrm{N}$ & 58,647 & 58,647 & 58,647 & 58,647 & 58,647 \\
\hline $\mathrm{R}^{2}$ overall & 0.0278 & 0.0285 & 0.0283 & 0.0285 & 0.0278 \\
\hline $\mathrm{R}^{2}$ between & 0.0869 & 0.0894 & 0.0897 & 0.0897 & 0.0887 \\
\hline $\mathrm{R}^{2}$ within & 0.3205 & 0.3210 & 0.3213 & 0.3211 & 0.3215 \\
\hline Sigma $u_{i}$ & 5.9719 & 5.8869 & 5.8117 & 5.8594 & 5.8118 \\
\hline Sigma $e_{i t}$ & 1.0686 & 1.0682 & 1.0681 & 1.0682 & 1.0679 \\
\hline Rho & 0.9690 & 0.9681 & 0.9673 & 0.9678 & 0.9673 \\
\hline
\end{tabular}

Clustered robust standard errors in parentheses ${ }^{*} p<0.05,{ }^{* *} p<0.01,{ }^{* * * *} p<0.001$

Table 4 - Preferred specification from Table 3 with dynamic policy trends at policy and project level added 


\begin{tabular}{|c|c|c|c|c|c|}
\hline $\begin{array}{l}\text { Dep.var.: } \\
\text { Log Employment }\end{array}$ & $\begin{array}{c}(1) \\
\text { did_wc1 }\end{array}$ & $\begin{array}{c}(2) \\
\text { did_wc2 }\end{array}$ & $\begin{array}{c}(3) \\
\text { did_wc3 }\end{array}$ & $\begin{array}{c}(4) \\
\text { did_wc4 }\end{array}$ & $\begin{array}{c}(5) \\
\text { did_wc5 }\end{array}$ \\
\hline Constasnt & $\begin{array}{c}1.4692 \\
(1.2971)\end{array}$ & $\begin{array}{l}1.2328 \\
(1.2871)\end{array}$ & $\begin{array}{c}1.1551 \\
(1.2871)\end{array}$ & $\begin{array}{l}1.1240 \\
(1.2826)\end{array}$ & $\begin{array}{c}1.1452 \\
(1.2848)\end{array}$ \\
\hline Wit & $\begin{array}{l}-0.0175 \\
(0.0193)\end{array}$ & $\begin{array}{c}0.3985^{* * *} \\
(0.0872)\end{array}$ & $\begin{array}{c}0.3371^{* * *} \\
(0.0848)\end{array}$ & $\begin{array}{c}0.3856^{* * * *} \\
(0.0820)\end{array}$ & $\begin{array}{c}0.4657^{* * * *} \\
(0.0860)\end{array}$ \\
\hline Wit*t & - & - & $\begin{array}{c}0.0062 \\
(0.0032)\end{array}$ & - & $\begin{array}{l}-0.0092^{*} \\
(0.0045)\end{array}$ \\
\hline Wit*ti & - & - & - & $\begin{array}{l}0.0092^{* *} \\
(0.0031)\end{array}$ & $\begin{array}{c}0.0171^{* * * *} \\
(0.0044)\end{array}$ \\
\hline Log Working Age Population & $\begin{array}{l}1.2982^{* * * *} \\
(0.1479)\end{array}$ & $\begin{array}{l}1.2686^{* * *} \\
(0.1495)\end{array}$ & $\begin{array}{l}1.2764^{* * *} \\
(0.1492)\end{array}$ & $\begin{array}{l}1.2777^{* * * *} \\
(0.1490)\end{array}$ & $\begin{array}{l}1.2740^{* * * *} \\
(0.1493)\end{array}$ \\
\hline Deviation for Wit & & $\begin{array}{l}-0.0886 \\
(0.0899)\end{array}$ & $\begin{array}{l}-0.0858 \\
(0.0895)\end{array}$ & $\begin{array}{l}-0.0890 \\
(0.0882)\end{array}$ & $\begin{array}{l}-0.0935 \\
(0.0884)\end{array}$ \\
\hline Log SOEs & $\begin{array}{c}0.0217 \\
(0.0245)\end{array}$ & $\begin{array}{c}0.0112 \\
(0.0293)\end{array}$ & $\begin{array}{c}0.0106 \\
(0.0293)\end{array}$ & $\begin{array}{c}0.0112 \\
(0.0293)\end{array}$ & $\begin{array}{c}0.0122 \\
(0.0293)\end{array}$ \\
\hline Deviation for Wit & & $\begin{array}{c}0.0362 \\
(0.0420)\end{array}$ & $\begin{array}{c}0.0579 \\
(0.0452)\end{array}$ & $\begin{array}{c}0.0659 \\
(0.0447)\end{array}$ & $\begin{array}{c}0.0594 \\
(0.0450)\end{array}$ \\
\hline Log Firms & $\begin{array}{l}-0.0550 \\
(0.0648)\end{array}$ & $\begin{array}{l}-0.0683 \\
(0.0654)\end{array}$ & $\begin{array}{l}-0.0718 \\
(0.0653)\end{array}$ & $\begin{array}{l}-0.0746 \\
(0.0654)\end{array}$ & $\begin{array}{l}-0.0749 \\
(0.0654)\end{array}$ \\
\hline Deviation for Wit & & $\begin{array}{c}0.1335 \\
(0.0729)\end{array}$ & $\begin{array}{c}0.1328 \\
(0.0729)\end{array}$ & $\begin{array}{c}0.1354 \\
(0.0721)\end{array}$ & $\begin{array}{c}0.1381 \\
(0.0721)\end{array}$ \\
\hline Log Foreign Firms & $\begin{array}{c}0.0411 \\
(0.0258)\end{array}$ & $\begin{array}{c}0.0456 \\
(0.0260)\end{array}$ & $\begin{array}{c}0.0450 \\
(0.0260)\end{array}$ & $\begin{array}{c}0.0446 \\
(0.0259)\end{array}$ & $\begin{array}{c}0.0447 \\
(0.0259)\end{array}$ \\
\hline Deviation for Wit & & $\begin{array}{l}-0.0170 \\
(0.0236)\end{array}$ & $\begin{array}{l}-0.0167 \\
(0.0235)\end{array}$ & $\begin{array}{l}-0.0203 \\
(0.0232)\end{array}$ & $\begin{array}{l}-0.0236 \\
(0.0233)\end{array}$ \\
\hline Log Education Expenditure & $\begin{array}{c}-0.1723^{* * * *} \\
(0.0387)\end{array}$ & $\begin{array}{c}-0.1489^{* * * *} \\
(0.0415)\end{array}$ & $\begin{array}{c}-0.1473^{* * * *} \\
(0.0415)\end{array}$ & $\begin{array}{c}-0.1464^{* * * *} \\
(0.0413)\end{array}$ & $\begin{array}{c}-0.1467^{* * * *} \\
(0.0413)\end{array}$ \\
\hline Deviation for Wit & & $\begin{array}{l}-0.0498 \\
(0.0579)\end{array}$ & $\begin{array}{l}-0.0652 \\
(0.0576)\end{array}$ & $\begin{array}{l}-0.0684 \\
(0.0570)\end{array}$ & $\begin{array}{l}-0.0616 \\
(0.0576)\end{array}$ \\
\hline Log Government Grants & $\begin{array}{l}-0.1953^{*} \\
(0.0895)\end{array}$ & $\begin{array}{l}-0.1794^{*} \\
(0.0864)\end{array}$ & $\begin{array}{l}-0.1785^{*} \\
(0.0861)\end{array}$ & $\begin{array}{l}-0.1769^{*} \\
(0.0855)\end{array}$ & $\begin{array}{l}-0.1760^{*} \\
(0.0852)\end{array}$ \\
\hline Deviation for Wit & & $\begin{array}{l}-0.0451 \\
(0.0576)\end{array}$ & $\begin{array}{l}-0.0320 \\
(0.0570)\end{array}$ & $\begin{array}{l}-0.0298 \\
(0.0567)\end{array}$ & $\begin{array}{l}-0.0360 \\
(0.0571)\end{array}$ \\
\hline Year fixed effects & Yes*** & Yes*** & Yes*** & Yes*** & Yes $* * *$ \\
\hline Number of obs. & 22,532 & 22,532 & 22,532 & 22,532 & 22,532 \\
\hline $\mathrm{R}^{2}$ overall & 0.0787 & 0.0916 & 0.0941 & 0.0962 & 0.0965 \\
\hline $\mathrm{R}^{2}$ between & 0.0910 & 0.1059 & 0.1089 & 0.1114 & 0.1117 \\
\hline $\mathrm{R}^{2}$ within & 0.1004 & 0.1034 & 0.1035 & 0.1037 & 0.1038 \\
\hline Sigma $u_{i}$ & 1.7229 & 1.6344 & 1.6248 & 1.6170 & 1.6163 \\
\hline Sigma $e_{i t}$ & 0.6435 & 0.6425 & 0.6425 & 0.6424 & 0.6424 \\
\hline Rho & 0.8776 & 0.8661 & 0.8648 & 0.8637 & 0.8636 \\
\hline
\end{tabular}

Notes: Clustered robust standard errors in parentheses ${ }^{*} p<0.05,{ }^{* * *} p<0.01,{ }^{* * * *} p<0.001$. a/ Mahalanobis distance matching on the following variables: employment, number of foreign firms, agricultural share of land, education expenditure per capita, government grants per capita and with exact matching on number of state owned enterprises and urban gmina dummy (sliced by state owned enterprises) using mahapick in Stata 11: 'mahapick employment firms_foreign agrishare education_cap govgrant_cap, idvar(code) genfile(mahalanobis) treated(sez) nummatches(5) matchon(firms_soe nuts51) sliceby(firms_soe)'.

Table 5a - Table 4 with Mahalanobis distance matching ${ }^{a}$ 


\begin{tabular}{|c|c|c|c|c|c|c|c|}
\hline Dep. Var.: & (1) & (2) & (3) & (4) & (5) & (6) & (7) \\
\hline Log Employment & Full sample & $\mathrm{SOE}_{\mathrm{t}=1995}>0$ & $\mathrm{SOE}_{\mathrm{t}=1995}>5$ & $\mathrm{SOE}_{\mathrm{t}=1995}>10$ & $\mathrm{SOE} t=1995>25$ & $\mathrm{SOE}_{\mathrm{t}=1995}>50$ & $\mathrm{SOE}_{\mathrm{t}=1995}>100$ \\
\hline \multirow[t]{2}{*}{ Constant } & $7.3157^{* * * *}$ & $7.2699^{* * *}$ & $8.3333^{* * *}$ & $9.6935^{* * *}$ & $22.2804^{* * *}$ & $15.2347^{*}$ & 2.3896 \\
\hline & $(0.9672)$ & $(0.9336)$ & $(1.0540)$ & $(1.4643)$ & $(3.5073)$ & $(6.9961)$ & (1.8493) \\
\hline \multirow[t]{2}{*}{ Wit } & $0.7699^{* * *}$ & $0.7646^{* * *}$ & $0.7559^{* * *}$ & $0.7435^{* * *}$ & $0.8360^{* * *}$ & $\begin{array}{l}-0.4476^{* *} \\
(01684)\end{array}$ & $\begin{array}{l}-0.3889 \\
-02415)\end{array}$ \\
\hline & $(0.0887)$ & $(0.0869)$ & $(0.0869)$ & $\begin{array}{l}(0.0937) \\
\left(0.0553^{* * * *}\right.\end{array}$ & $(0.1160)$ & (0.1684) & $(0.2415)$ \\
\hline \multirow[t]{2}{*}{ Wit*t } & $-0.0641^{* * * *}$ & $-0.0622^{* * * *}$ & $-0.0604^{* * * *}$ & $-0.0553^{* * * *}$ & $-0.0711^{* * * *}$ & -0.0164 & 0.0005 \\
\hline & $(0.0061)$ & $(0.0060)$ & $(0.0060)$ & $(0.0066)$ & $(0.0110)$ & (0.0099) & (0.0042) \\
\hline \multirow[t]{2}{*}{ Wit*ti } & $0.0470^{* * *}$ & $0.0468^{* * *}$ & $0.0455^{* * *}$ & $0.0387^{* * *}$ & $0.0359^{* * *}$ & 0.0032 & 0.0039 \\
\hline & $(0.0053)$ & $(0.0052)$ & $(0.0052)$ & $(0.0055)$ & $(0.0075)$ & $(0.0034)$ & $(0.0031)$ \\
\hline \multirow[t]{2}{*}{ Log Work. Age Pop. } & $0.7450^{* * * *}$ & $0.7559^{* * * *}$ & $0.7432^{* * *}$ & $0.9983^{* * * *}$ & 0.3945 & 0.3588 & $0.7168^{* * *}$ \\
\hline & $(0.1301)$ & $(0.1261)$ & $(0.1383)$ & $(0.1978)$ & $(0.4137)$ & $(0.2492)$ & $(0.1865)$ \\
\hline \multirow[t]{2}{*}{ Deviation in Wit } & -0.1685 & -0.1803 & -0.1405 & -0.1075 & -0.0523 & $-0.2207^{*}$ & $-0.2725^{* *}$ \\
\hline & $(0.1060)$ & $(0.1054)$ & $(0.1039)$ & $(0.1116)$ & $(0.1530)$ & $(0.1073)$ & (0.0886) \\
\hline \multirow[t]{2}{*}{ Log SOEs } & $-0.0808^{*}$ & -0.0404 & -0.0356 & -0.0057 & 0.0456 & 0.0275 & $-0.0287^{* *}$ \\
\hline & $(0.0317)$ & $(0.0310)$ & $(0.0326)$ & $(0.0371)$ & $(0.0579)$ & $(0.0491)$ & (0.0104) \\
\hline \multirow[t]{2}{*}{ Deviation in Wit } & $0.1548^{* * *}$ & $0.1251^{* *}$ & $0.1129^{*}$ & 0.0764 & -0.0232 & -0.0345 & -0.0032 \\
\hline & $(0.0475)$ & $(0.0467)$ & $(0.0460)$ & $(0.0484)$ & $(0.0635)$ & $(0.0392)$ & $(0.0117)$ \\
\hline \multirow[t]{2}{*}{ Log Firms } & 0.1066 & 0.0285 & -0.0116 & -0.1866 & -0.0384 & -0.0650 & -0.0471 \\
\hline & $(0.0591)$ & $(0.0594)$ & $(0.0671)$ & $(0.0987)$ & $(0.2871)$ & $(0.0950)$ & $(0.0765)$ \\
\hline \multirow[t]{2}{*}{ Deviation in Wit } & 0.1802 & $0.2165^{*}$ & 0.1822 & 0.1981 & 0.2968 & 0.1611 & $0.2378^{* *}$ \\
\hline & $(0.0960)$ & $(0.0955)$ & (0.0949) & $(0.1028)$ & $(0.1637)$ & $(0.1128)$ & $(0.0872)$ \\
\hline \multirow[t]{2}{*}{ Log Foreign Firms } & $0.0496^{*}$ & $0.0570^{*}$ & 0.0464 & 0.0698 & 0.0578 & 0.0838 & 0.0252 \\
\hline & $(0.0226)$ & $(0.0231)$ & $(0.0257)$ & $(0.0372)$ & $(0.0928)$ & $(0.0682)$ & $(0.0357)$ \\
\hline \multirow[t]{2}{*}{ Deviation in Wit } & $-0.0662^{*}$ & $-0.0684^{*}$ & $-0.0621^{*}$ & -0.0465 & $-0.0923^{*}$ & -0.0318 & -0.0195 \\
\hline & $(0.0276)$ & $(0.0275)$ & $(0.0281)$ & $(0.0305)$ & $(0.0457)$ & $(0.0430)$ & $(0.0228)$ \\
\hline \multirow[t]{2}{*}{ Log Education Exp. } & $-0.3671^{* * * *}$ & $-0.3296^{* * * *}$ & $-0.3148^{* * * *}$ & $-0.1424^{* * * *}$ & 0.1456 & $-0.2720^{*}$ & 0.0274 \\
\hline & $(0.0686)$ & $(0.0654)$ & $(0.0784)$ & $(0.0377)$ & $(0.0968)$ & $(0.1128)$ & $(0.0421)$ \\
\hline \multirow{2}{*}{ Deviation in Wit } & 0.0393 & 0.0154 & 0.0063 & -0.1414 & -0.1798 & $0.1634^{* *}$ & 0.0492 \\
\hline & $(0.0819)$ & $(0.0796)$ & $(0.0873)$ & $(0.0737)$ & $(0.0958)$ & $(0.0615)$ & $(0.0519)$ \\
\hline \multirow[t]{2}{*}{ Log Gov. Grants } & $-0.3613^{* * * *}$ & $-0.3390^{* * * *}$ & $-0.3734^{* * *}$ & $-0.6828^{* * *}$ & $-1.4391^{* * *}$ & -0.2562 & 0.0056 \\
\hline & $(0.0996)$ & $(0.0957)$ & $(0.1202)$ & $(0.0444)$ & $(0.1326)$ & $(0.1803)$ & $(0.0544)$ \\
\hline \multirow[t]{2}{*}{ Deviation in Wit } & -0.1133 & -0.0921 & -0.0836 & 0.0499 & 0.0832 & -0.0511 & 0.0129 \\
\hline & $(0.0825)$ & $(0.0801)$ & $(0.0882)$ & $(0.0733)$ & $(0.0967)$ & $(0.0419)$ & $(0.0446)$ \\
\hline Year fixed effects & Yes $^{* * *}$ & Yes $^{* * *}$ & $\mathrm{Yes}^{* * *}$ & $\mathrm{Yes}^{* * *}$ & $\mathrm{Yes}^{* * *}$ & Yes** & Yes $^{* *}$ \\
\hline Number of obs. & 58,647 & 55,360 & 45,399 & 25,531 & 7,060 & 2,432 & 861 \\
\hline $\mathrm{R}^{2}$ overall & 0.0278 & 0.0263 & 0.0192 & 0.0207 & 0.1476 & 0.0982 & 0.9393 \\
\hline $\mathrm{R}^{2}$ between & 0.0887 & 0.0884 & 0.0648 & 0.0604 & 0.3777 & 0.1036 & 0.9436 \\
\hline $\mathrm{R}^{2}$ within & 0.3215 & 0.3147 & 0.2853 & 0.2510 & 0.2269 & 0.0492 & 0.6309 \\
\hline Sigma $_{\mathrm{i}}$ & 5.8118 & 5.2724 & 5.2289 & 5.9424 & 9.1601 & 1.6529 & 0.3838 \\
\hline Sigma $_{i t}$ & 1.0679 & 1.0508 & 1.0539 & 1.0828 & 1.1288 & 0.3639 & 0.0413 \\
\hline Rho & 0.9673 & 0.9618 & 0.9610 & 0.9679 & 0.9850 & 0.9538 & 0.9885 \\
\hline Sampled full/in treat & $3,829 / 462$ & $3,551 / 453$ & $2,915 / 431$ & $1,644 / 370$ & $455 / 218$ & $156 / 113$ & $57 / 50$ \\
\hline
\end{tabular}

Clustered robust standard errors in parentheses ${ }^{*} p<0.05,{ }^{* *} p<0.01,{ }^{* * *} p<0.001$

Table $5 b$ - Preferred specification from Table 4 (Column 5) with sample selection for number of SOEs by area in 1995 


\begin{tabular}{|c|c|c|c|c|c|}
\hline Dep. var. & (1) & (2) & (3) & (4) & (5) \\
\hline Log Employment (FD) & GMM & GMM & GMM & GMM & GMM \\
\hline \multirow[t]{2}{*}{ Constant } & 1.8252 & 2.4565 & 0.7717 & 2.4499 & $-4.6386^{*}$ \\
\hline & $(1.5773)$ & (1.5934) & (1.6476) & $(1.5931)$ & $(1.9422)$ \\
\hline \multirow[t]{2}{*}{ LDV (FD) } & $0.4635^{* * * *}$ & $0.4636^{* * * *}$ & $0.4630^{* * * *}$ & $0.4636^{* * * *}$ & $0.4592^{* * *}$ \\
\hline & $(0.0020)$ & $(0.0020)$ & $(0.0020)$ & $(0.0020)$ & $(0.0022)$ \\
\hline \multirow[t]{2}{*}{ Log SOEs (predetermined) } & $0.1003^{* * *}$ & $0.1180^{* * * *}$ & $0.2163^{* * *}$ & $0.1184^{* * *}$ & $0.4803^{* * *}$ \\
\hline & $(0.0290)$ & $(0.0297)$ & $(0.0424)$ & $(0.0341)$ & $(0.0699)$ \\
\hline \multirow[t]{2}{*}{ Wit (endogenous) } & $0.1732^{* * * *}$ & $0.2813^{* * *}$ & $0.4030^{* * * *}$ & $0.2824^{* * *}$ & $0.0883^{* * *}$ \\
\hline & $(0.0189)$ & $(0.0243)$ & $(0.0404)$ & $(0.0331)$ & $(0.0250)$ \\
\hline \multirow[t]{2}{*}{ Wit*t (endogenous) } & - & - & $0.0365^{* * *}$ & - & $0.3254^{* * *}$ \\
\hline & & & $(0.0071)$ & & $(0.0394)$ \\
\hline \multirow[t]{2}{*}{ Wit*ti (endogenous) } & - & - & - & 0.0002 & $-0.2928^{* * * *}$ \\
\hline & & & & $(0.0052)$ & $(0.0347)$ \\
\hline \multirow[t]{2}{*}{ Log Working Age Pop. (FD) } & $-1.0979^{* * *}$ & $-1.1886^{* * *}$ & $-0.7545^{* *}$ & $-1.1869^{* * *}$ & 0.6051 \\
\hline & $(0.2473)$ & $(0.2498)$ & $(0.2632)$ & $(0.2505)$ & $(0.3129)$ \\
\hline \multirow[t]{2}{*}{ Log Firms (FD) } & $1.1377^{* * * *}$ & $1.1520^{* * * *}$ & $1.1240^{* * * *}$ & $1.1519^{* * * *}$ & $0.9475^{* * * *}$ \\
\hline & $(0.0923)$ & $(0.0925)$ & $(0.0934)$ & $(0.0926)$ & $(0.1013)$ \\
\hline \multirow[t]{2}{*}{ Log Foreign Firms (FD) } & $0.1034^{*}$ & $0.1046^{*}$ & 0.0840 & $0.1045^{*}$ & 0.0126 \\
\hline & $(0.0474)$ & $(0.0474)$ & $(0.0476)$ & $(0.0474)$ & $(0.0489)$ \\
\hline \multirow[t]{2}{*}{ Log Education Exp. (FD) } & $0.5965^{* * * *}$ & $0.6017^{* * * *}$ & $0.5226^{* * *}$ & $0.6013^{* * *}$ & $0.3248^{* * * *}$ \\
\hline & $(0.0292)$ & $(0.0295)$ & $(0.0257)$ & $(0.0281)$ & $(0.0311)$ \\
\hline \multirow[t]{2}{*}{ Log Gov. Grants (FD) } & $-0.2559^{* * *}$ & $-0.2578^{* * *}$ & $-0.3505^{* * *}$ & $-0.2581^{* * * *}$ & $-0.6199^{* * * *}$ \\
\hline & $(0.0354)$ & $(0.0354)$ & $(0.0400)$ & $(0.0359)$ & $(0.0579)$ \\
\hline $\mathrm{N}$ & 51,054 & 51,054 & 51,054 & 51,054 & 51,054 \\
\hline chi $^{2}$ & 72,782 & 74,791 & 77,230 & 79,316 & 56,018 \\
\hline$\sigma^{2}$ & 1.1859 & 1.1863 & 1.1871 & 1.1863 & 1.2174 \\
\hline
\end{tabular}

Table 6 - Preferred specification from Table 3 estimated with GMM and policy variables as endogenous 